United States

Department of

Agriculture

Forest Service

Intermountain

Forest and Range

Experiment Station

Ogden, UT 84401

Research Paper

INT-337

March 1985

Predicting Duff and Woody Fuel

Consumed by

Prescribed Fire in

ins.

\title{
the Northern Rocky Mountains
}

James K. Brown

Michael A. Marsden

Kevin C. Ryan
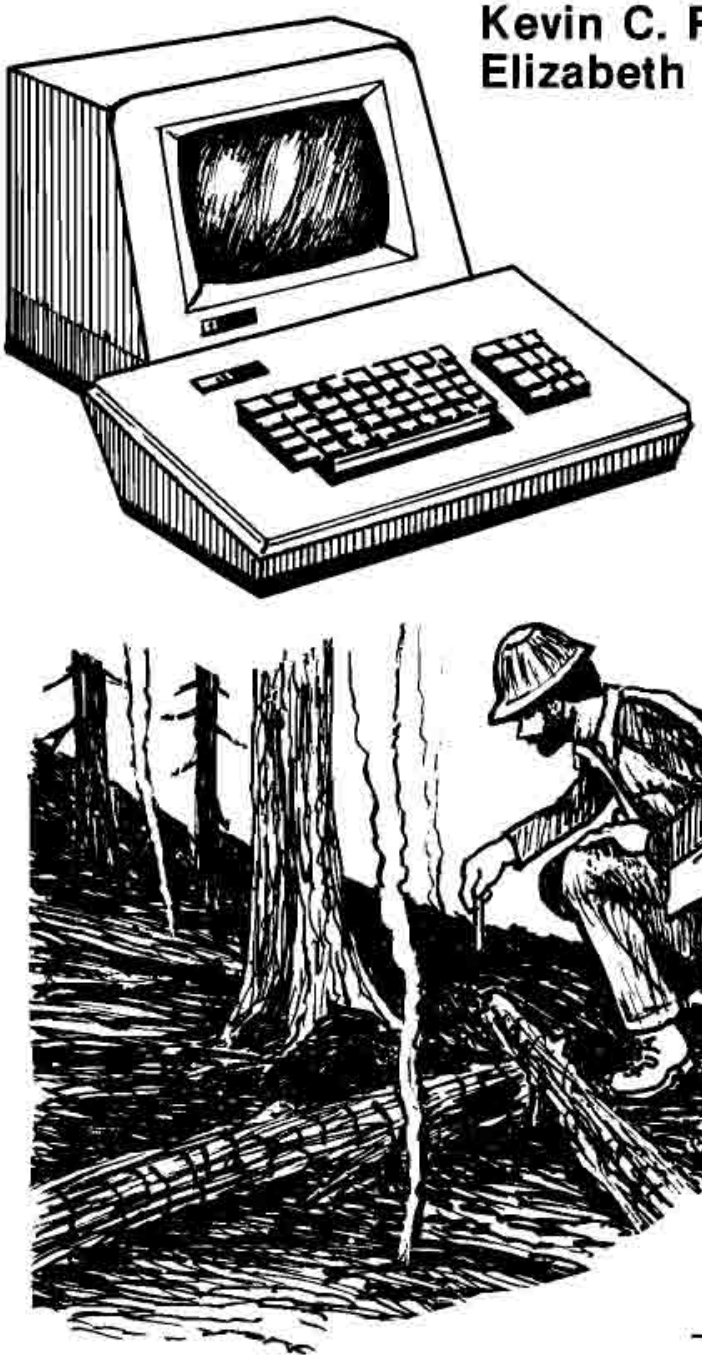

\author{
inhardt
}




\section{THE AUTHORS}

JAMES K. BROWN received his bachelor's degree from the University of Minnesota in 1960, his master's from Yale University in 1961, and his Ph.D. from the University of Michigan in 1968, all in forestry. From 1961 to 1965 , he did research on field measurement of fuel properties and fire-danger rating systems while with the Lake States Forest Experiment Station. In 1965, he transferred to the Northern Forest Fire Laboratory, Missoula, MT, where he conducted research on the physical properties, inventory, and prediction of fuels. Since 1979, he has been leader of a fire effects and use project in Missoula.

MICHAEL A. MARSDEN began his career as a forestry aid at the Forest Insect Research Laboratory, Beltsville, MD, in 1960. He received his B.S. from Utah State University in 1963 (applied statistics), and his M.S. from Colorado State University in 1973 (forest biometry). He was employed as a statistician for the Intermountain Forest and Range Experiment Station from 1963 through 1982. During this time he was stationed first at the Forestry Sciences Laboratory at Moscow, ID, and later at the Northern Forest Fire Laboratory. His present position is a biometrician with the Methods Application Group of Forest Pest Management Staff (Washington Office) stationed at Fort Collins, $\mathrm{CO}$.

KEVIN C. RYAN received his bachelor's degree in forest biology from Colorado State University in 1973 and his master's degree in forest ecology, also from Colorado State University, in 1976. From 1975 to 1976, he did prescribed fire research at the Rocky Mountain Forest and Range Experiment Station, Fort Collins, CO. In 1976, he transferred to the Pacific Northwest Forest and Range Experiment Station, Seattle, WA, where he conducted research on prescribed burning in mixed conifer shelterwoods. Since 1979 he has been at the Northern Forest Fire Laboratory, where he is involved in research on predicting the effects of fire on fuels, soils, and vegetation in the coniferous forests of the Northern Rocky Mountains.

ELIZABETH D. REINHARDT received a bachelor's degree in English from Harvard University in 1978 and a master's degree in forestry from the University of Montana in 1982. She is currently employed as an operations research analyst at the Northern Forest Fire Laboratory.

\section{RESEARCH SUMMARY}

Relationships for predicting consumption of forest floor duff and downed, dead, woody fuel were determined to assist managers in planning prescribed fires. Data were analyzed from three previous prescribed fire studies in slash and nonslash fuels in cover types comprising a mixture of western larch, Douglas-fir, ponderosa pine, lodgepole pine, Engelmann spruce, subalpine fir, and grand fir. Duff depth reduction, percentage duff depth reduction, and percentage mineral soil are shown as regression functions of lower duff moisture content, entire duff moisture content, $\mathrm{Na}$ tional Fire-Danger Rating System (NFDR) 1,000-hour moisture content, Canadian Adjusted Duff Moisture Code, preburn downed woody fuel loading, and preburn duff depth. Tests of the duff consumption relationships against other published data support their wide application.

Lower duff moisture content was the best predictor. Preburn downed woody fuel loading was of minor importance in the relationships. The NFDR 1,000-hour moisture predicted duff consumption with adequate precision for general guidance in developing fire prescriptions.

The NFDR 1,000-hour moisture was a better predictor of duff consumption and lower duff moisture than were two Canadian Duff Moisture Codes. The relationship between percentage mineral soil exposure and percentage duff reduction indicates that combustion in duff progresses both downward and laterally.

Consumption of downed woody fuel correlated strongly with preburn loadings. Percentage consumption, however, related weakly to all independent variables. Consumption differed substantially between slash (81 percent) and nonslash (46 percent). An evaluation of Sandberg and Ottmar's (1983) diameter reduction model based on large pieces of fresh slash underestimated by 35 percent the consumption of mostly rotten nonslash fuels, indicating the extent that consumption differs between sound and rotten material. 


\title{
Predicting Duff and Woody Fuel Consumed by Prescribed Fire in the Northern Rocky Mountains
}

\author{
James K. Brown \\ Michael A. Marsden \\ Kevin C. Ryan \\ Elizabeth D. Reinhardt
}

\section{INTRODUCTION}

Predicting the consumption of forest floor duff is essential to skillful planning of prescribed fires. Duff includes both the fermentation and humus layers of the forest floor. Soil scientists call duff the 02 soil horizon. Duff lies below the litter and above mineral soil. Duff influences many facets of the forest ecosystem; thus broad ecological knowledge is needed to evaluate the effects of its combustion. Duff and associated downed woody fuel must often be removed to reduce fire hazard, prepare seedbeds, kill selected vegetation, and stimulate desired plants. In contrast, retention of duff and woody material may be needed to protect sites from sun and erosion, enhance microbial activity, and provide small animal habitat. Smoke from the burning of duff may adversely affect air quality. To successfully accomplish the sometimes complex objectives of prescribed fires, consumption of duff and woody fuel must be competently planned and executed.

This paper presents numerical relationships of known precision for predicting duff consumption. They were established by assembling and analyzing data from three previous prescribed fire investigations and then testing them against other published data. Fuel loadings by diameter classes that differed among the studies were converted to a common set of diameter classes. The purpose of assimilating data from several studies was to develop predictive models that could be easily used by practitioners and that would apply over a wide range of conditions.

Duff consumption is often expressed in three ways: depth reduction, percentage depth reduction, and percentage mineral soil exposed. Each expression is appropriate to evaluating certain prescribed fire objectives. Mineral soil exposure, for example, is commonly used to define site preparation needs. Depth of duff reduction relates to actual amount consumed and smoke production. Percentage duff reduction is useful for describing and setting objectives of prescribed fire to leave specified amounts of duff on site.

Consumption of duff is strongly influenced by moisture content. Van Wagner (1972)developed a model of duff consumption based on theoretical considerations of variation of flame emissivity with water content. Empirical coefficients for the model were derived from jack pine (Pinus banksiana), red pine (Pinus resinosa), and eastern white pine (Pinus strobus) stands in eastern Canada. Sandberg (1980)found that Van Wagner's models required modifications to provide good predictions for underburning in partially cut Douglas-fir stands in Washington and Oregon.

Sandberg's (1980)findings, and those by Artley and others (1978), Norum (1977), and Shearer (1975)in western Montana agreed well and suggested that duff burns independently of surface fuels below a duff moisture content of about 30 percent. In contrast, burning is meager above a moisture content of about 120 percent. Between these moisture limits, combustion of duff appears related to its moisture content and heat from surface fire. Other factors such as preburn duff depth and physical disturbances of duff may also influence the degree of consumption. Because prescribed burning is frequently done at duff moisture contents between 30 and 120 percent, the relationships for predicting consumption need to be better understood and quantified.

Some fire weather indices correlate reasonably well to duff consumption. For example, Van Wagner (1972)and Chrosciewicz (1978a,b) related duff consumption to the Duff Moisture Code of the Canadian Fire Weather System. Beaufait and others (1977)regressed duff consumption against upper duff moisture content and the Buildup Index from the old National Fire-Danger Rating System (USDA Forest Service 1964). Sandberg (1980)developed equations for predicting duff depth reduction and mineral soil exposure from the National Fire-Danger Rating System (NFDR)1,000-hour moisture model (Deeming and others 1977). Although fire-danger rating indices relate only indirectly to duff moisture content, they are easily determined. Thus, relationships between fire-danger rating indices and duff consumption can be valuable for planning if they are adequately precise. Additional investigation is needed to confirm or modify Sandberg's findings with the widely used NFDR 1.000-hour moisture model. 
Mineral soil exposure following fire can vary considerably. Efforts to predict exposure have sometimes been unsuccessful (Van Wagner 1972; Chrosciewicz 1978a,b).

Norum's (1977)procedure for predicting mineral soil exposure, which assumes that duff burns off in uniform layers, was successful in a study of undisturbed fuels, but was unsuccessful when applied following partial cuttings (Sandberg 1980). Physical disturbance of the duff and a tendency for duff to burn laterally rather than downward may cause inconsistent results when using this method.

Martin and others (1979)concluded that fuels less than M-inch diameter are almost completely consumed by fire over a wide range of environmental conditions. Branchwood from M- to 3-inch diameter is largely consumed. Norum (1976)found that consumption of 0 - to M-inch, M- to 1-inch, and 1- to 3-inch diameter woody fuels was strongly correlated to preburn loading of these fuels and moisture content. Other than this, little has been reported on predictive equations for consumption of small, downed, woody fuels (3-inch diameter and smaller).

Consumption of large woody fuels (larger than 3-inch diameter) depends primarily on their moisture content, degree of rot, and arrangement. Albini 11976) developed a theoretical model that predicts consumption of large fuels and time history of intensity. The model, which is largely untested, assumes a random distribution of pieces and depends on moisture content and planform overlap. In underburning of natural fuels, Norum (1976) found that moisture content and loading of smaller fuels were significant predictors of large fuel consumption.

Sandberg and Ottmar (1983), in cable-yarded logging debris, observed that unit average consumption was not influenced by piece arrangement, species composition, or age of slash. They furnished equations for estimating large fuel consumption as a function of fuel moisture content.

By examining data from several sources, this study furnishes predictive equations over a wide range of preburn fuel conditions. Experimental fires in slash and nonslash fuels from several cover types and ignited in varying patterns are included in the analysis. A new technique is used to evaluate exposure of mineral soil. The predictive equations include one or two independent variables readily obtained by practitioners. Practical results are presented in a section on management applications and the details of analysis discussed in another section.

\section{METHODS}

Data from the following prescribed burn studies in western Montana and northern Idaho were assimilated and analyzed:

1. Beaufait and others (1977) - Thisstudy was conducted in clearcut logging slash created in old-growth forests when utilization standards were less stringent than today (fig. 1). This was perhaps the first study in

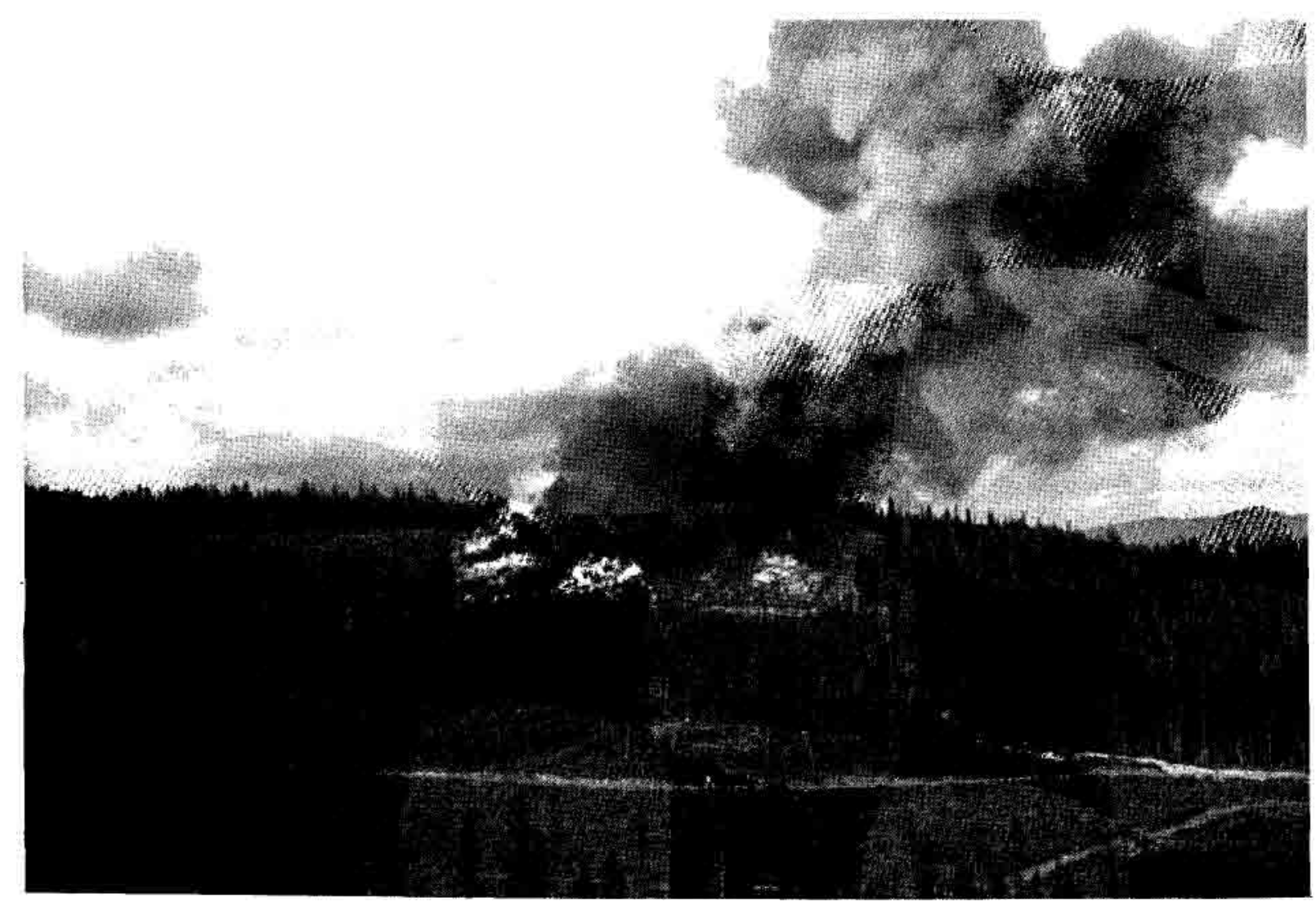

Figure 7. - A broadcast burn in clearcut logging slash at Miller Creek. 
the Western United States to relate burn accomplishment to fuel quantity and moisture content quantitatively. Slashing and directional felling were used to maintain fuel continuity. No mechanical preparation was done within the study units. The study is referred to as Miller Creek-Newman Ridge (MN) in this paper.

2. Norum (1976)-This study occurred in an uncut mature stand dominated by Douglas-fir (fig. 2). It was prompted by the need for guides to assist in the planning of underburns to reduce fuels. This study is referred to as Lubrecht (L). Data were analyzed as spring (Ls) and fall (Lf) sets.

3. Baaken and Neuenschwander (1981)-This study was conducted in seral ponderosa pine stands that had been selectively harvested followed by mechanical piling in 1978. Logging disturbance to the surface fuel and soil varied substantially among units. The purpose of the study was to relate preburn conditions and fire behavior to accomplishment of silvicultural objectives. This study site is referred to as northern Idaho (NI).

Study sites are described further in table 1.

Analysis of duff was emphasized in this report because the data were sampled with respectable reliability in all studies and promised to offer relationships useful to planning of prescribed fires. Small woody fuel, which in-

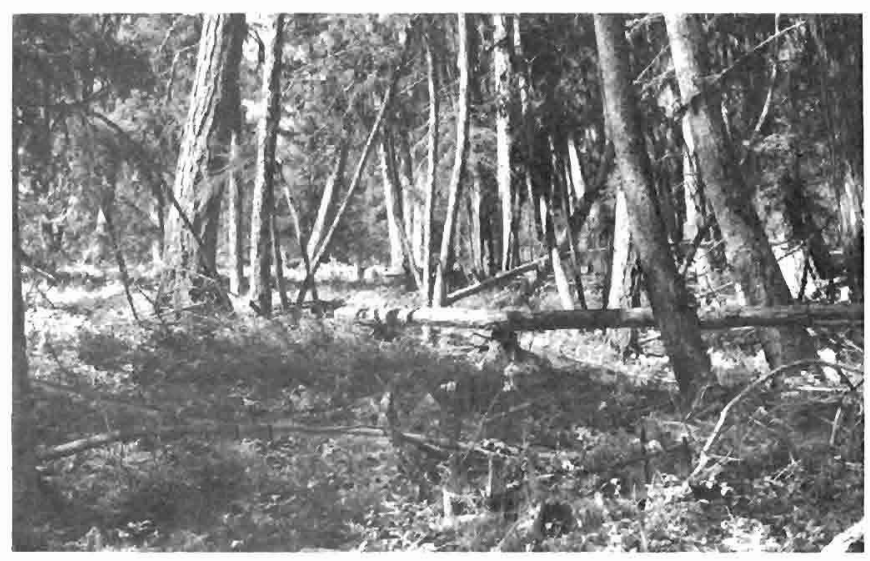

Figure 2.-Fuel and stand conditions prior to underburning a unit at Lubrecht.

cludes material less than 3 inches in diameter, was also adequately sampled in all studies and was used as an independent variable to predict duff consumption. Sampling of large fuels, however, was adequate only for Lubrecht and northern Idaho. Our analysis was directed at determining relationships not explored in the other studies and examining relationships from combined data.

Table 1.-Description of study sites

\begin{tabular}{|c|c|c|c|}
\hline Site & Miller-Newman & Lubrecht & Northern Idaho \\
\hline Location & $\begin{array}{l}\text { Flathead and Lolo } \\
\text { National Forests, } \\
\text { MT }\end{array}$ & $\begin{array}{l}\text { University of Montana } \\
\text { Lubrecht Experimental } \\
\text { Forest, MT }\end{array}$ & $\begin{array}{l}\text { Coeur d'Alene } \\
\text { Indian Reservation, } \\
\text { ID }\end{array}$ \\
\hline Cover type & $\begin{array}{l}\text { Western larch/ } \\
\text { Douglas-fir } \\
\text { primarily; other } \\
\text { species were grand fir, } \\
\text { ponderosa pine, } \\
\text { lodgepole pine, } \\
\text { subalpine fir, } \\
\text { Engelmann spruce, and } \\
\text { western white pine }\end{array}$ & $\begin{array}{l}\text { Western larch/Douglas - } \\
\text { fir }\end{array}$ & $\begin{array}{l}\text { Ponderosa pine; } \\
\text { sparse Douglas - fir } \\
\text { understory }\end{array}$ \\
\hline $\begin{array}{l}\text { Plot size, } \\
\text { acres }\end{array}$ & $2 \cdot 1 / 2$ & $1 / 3$ & $1 / 2$ to $2 \frac{1}{2}$ \\
\hline $\begin{array}{l}\text { Slope, } \\
\text { percent }\end{array}$ & 9 to 76 & 20 to 50 & 0 to 30 \\
\hline $\begin{array}{l}\text { Elevation, } \\
\text { feet }\end{array}$ & 4,200 to 5,400 & 4,790 & 2,590 to 2,890 \\
\hline Burn dates & $\begin{array}{l}\text { May, June, July, } \\
\text { Aug., Sept., Oct., } \\
1967-69\end{array}$ & $\begin{array}{l}\text { May, June, July, } \\
\text { Sept., Oct., } \\
1973\end{array}$ & Sept., Oct., 1978 \\
\hline $\begin{array}{l}\text { Dead } 1 \text {-hol } \\
\text { timelag fuel } \\
\text { moisture, } \\
\text { percent }\end{array}$ & 6 to 21 & 9 to 35 & 9 to 21 \\
\hline $\begin{array}{l}\text { Ignition } \\
\text { pattern }\end{array}$ & Single headfire & Strip headfire & $\begin{array}{l}\text { Strip headfire, } \\
\text { single headfire, } \\
\text { backfire }\end{array}$ \\
\hline
\end{tabular}


Small fuel loadings ranged from 0.1 to 36 tons/acre 10.2 to $81 \mathrm{t} / \mathrm{ha}$ ). Duff depths ranged from 0.1 to 4.3 inches $(0.3$ to $11 \mathrm{~cm})$. Ranges of all variables and their abbreviations are shown in table 2.

To facilitate comparison of data for small, woody fuels, loadings by diameter class for Miller Creek and Newman Ridge were converted to the conventional 0 - to $1 / 4$-inch (0- to $0.6-\mathrm{cm}), 1 / 4$ - to 1 -inch $(0.6-$ to $2.5-\mathrm{cm})$, and $1-$ to 3 -inch (2.5- to 7.6-cm) classes, appendix I. These correspond to the NFDR 1-, 10-, and 100-hour average moisture timelag size classes (Fosberg 1970) adhered to in the other studies.
No attempt was made to model fuel reduction separately for $0-$ to $1 / 4$-inch, $1 / 4-$ to 1 -inch, and 1- to 3 -inch classes. Instead, diameter classes were grouped. Woody fuels 0 to 1 inch and 0 to 3 inches were analyzed as separate variables. Fuel consumption for $0-$ to $1 / 4-$ inch, $1 / 4-$ to 1 -inch, and 1- to 3 -inch classes was not evaluated because incomplete combustion may cause woody pieces to change diameter classes. This introduces error in determining consumption for any single class. The 0 - to 1 -inch and 0 - to 3 -inch classes were considered large enough to furnish reasonably accurate estimates of consumption by minimizing these errors.

Table 2.-Ranges of variables studied

\begin{tabular}{|c|c|c|c|c|c|}
\hline \multirow[b]{2}{*}{ Variable } & \multirow[b]{2}{*}{ Abbreviation } & \multicolumn{3}{|c|}{ Study Location' } & \multirow[b]{2}{*}{ NI } \\
\hline & & MN & $\mathrm{L}_{1}$ & $L_{s}$ & \\
\hline $\begin{array}{l}\text { Duff depth reduction, } \\
\text { percent }\end{array}$ & $\mathrm{DR} \%$ & 1 to 100 & 23 to 73 & 14 to 35 & 0 to 56 \\
\hline $\begin{array}{l}\text { Mineral soil exposure, } \\
\text { percent }\end{array}$ & $M \%$ & 0 to 93 & 1 to 51 & 0 to 16 & - \\
\hline $\begin{array}{l}\text { Duff depth reduction, } \\
\text { inches }\end{array}$ & DR & 0 to 2.4 & 0.6 to 3.0 & 0.5 to 1.1 & 0 to 1.1 \\
\hline $\begin{array}{l}\text { Preburn duff depth, } \\
\text { inches }\end{array}$ & DPRE & 0.1 to 3.2 & 1.7 to 4.3 & 2.0 to 3.3 & 0.6 to 2.6 \\
\hline $\begin{array}{l}\text { Lower duff moisture } \\
\text { content, percent }\end{array}$ & LDM & 40 to 219 & 23 to 103 & 40 to 145 & - \\
\hline $\begin{array}{l}\text { Entire duff moisture } \\
\text { content, percent }\end{array}$ & EDM & 30 to 221 & 16 to 102 & 28 to 106 & 9 to 46 \\
\hline $\begin{array}{l}\text { NFDR } 1,000 \text { - hour } \\
\text { timelag moisture } \\
\text { content, percent }\end{array}$ & $\mathrm{TH}$ & 7 to 25 & 11 to 15 & 13 to 18 & 17 to 20 \\
\hline $\begin{array}{l}\text { Canadian Adjusted } \\
\text { Duff Moisture Code }\end{array}$ & ADMC & 13 to 249 & 91 to 162 & 26 to 86 & 33 to 119 \\
\hline $\begin{array}{l}\text { Preburn } 0-3 \text {-inch } \\
\text { woody fuel load, } \\
\text { tons/acre }\end{array}$ & WT3 & 12.84 to 35.80 & 1.44 to 7.68 & 1.33 to 4.27 & 0.10 to 11.06 \\
\hline $\begin{array}{l}0-3 \text {-inch woody fuel } \\
\text { consumed, tons/acre }\end{array}$ & CWT3 & 8.07 to 29.88 & 0.23 to 6.41 & 0 to 2.13 & 0 to 10.40 \\
\hline $\begin{array}{l}\text { Preburn } 0-1 \text {-inch } \\
\text { woody fuel load, } \\
\text { tons/acre }\end{array}$ & WT1 & 3.44 to 14.80 & 0.55 to 2.13 & 0.64 to 1.13 & 0.03 to 10.27 \\
\hline $\begin{array}{l}\text { Preburn } 3+- \text { inch } \\
\text { woody fuel load, } \\
\text { tons/acre }\end{array}$ & WTLG & - & 4.84 to 47.96 & 9.55 to 46.92 & 0 to 37.44 \\
\hline $\begin{array}{l}3+\text { woody fuel } \\
\text { consumed, tons/acre }\end{array}$ & CWTLG & - & 0 to 41.10 & 3.16 to 39.43 & 0 to 16.97 \\
\hline $\begin{array}{l}\text { Reaction intensity, } \\
\text { Btu/min/ft }\end{array}$ & RI & 1,321 to 5,881 & 46 to 2,677 & 431 to 1,872 & 826 to 5,302 \\
\hline
\end{tabular}

${ }^{1} M N=$ Miller-Newman; $L_{f}=$ Lubrecht, fall; $L_{s}=$ Lubrecht, spring; $N I=$ northern Idaho 
A strategy for analysis involved these steps:

1. Examine scattergrams to identify outliers and possible relationships. A few implausible outliers were discarded.

2. Perform regression analysis on candidate relationships for separate and pooled data sets. Criteria followed in determining functional relationships were to keep functional forms as simple as possible, keep the number of variables to a minimum, and involve only variables that have a physical reason for existence and can be obtained by managers.

3. Select good-fitting relationships: regressions that have low standard errors of estimate and predict well for other data sets. Goodness-of-fit of given functions to their own and to other data sets was evaluated using the average difference between observed and predicted values to indicate bias (table 3 ). The root mean square of differences between observed and predicted values provided estimates of precision. Standard errors of the estimate from regression analysis were numerically close to the root mean square of differences. They differed only in that the denominator for the standard error was degrees of freedom rather than number of observations. Standard errors and $r^{2}$ values for several segmented regressions were based on data for both segments.

4. Pick the best fitting relationships and test them against other fuel consumption data and relationships in the literature. "Best" equations were those having the smallest standard errors and most consistent predictions.

\section{Preliminary Duff Analysis}

Determination of mineral soil exposure.-Mineral soil exposure was not observed directly on the study sites. Instead, it was calculated from preburn and postburn duff depths measured at duff spikes (fig. 3). Mineral soil was considered exposed when 0.4 inch $(1.0 \mathrm{~cm})$ or less of unburned organic material was left after a fire. This criterion of mineral soil was chosen because postfire duff less than 0.5 inch $(1.3 \mathrm{~cm})$ in depth can be considered mineral soil for germinating seedlings (DeByle 1981; Shearer 1983). Germinating seedlings can penetrate through 0.5 inch of duff to become established in mineral soil. Also, additional duff reduction due to physical deterioration and decomposition seems to occur during the year or so following fire. This reduces residual duff even further beyond its immediate postfire quantity. A third reason for the $0.4-i n c h(1.0-\mathrm{cm})$ residual duff criterion is that residual duff depths cannot be measured very accurately until more than about 0.2 inch $(0.5 \mathrm{~cm})$ of duff is present. Scattergrams of percentage mineral soil versus median residual duff depth, using 0.2 inch and 0.4 inch as criteria for mineral soil showed less scatter for the 0.4-inch criterion. Thus, a 0.4-inch residual depth appeared large enough to measure accurately and small enough to qualify as a mineral soil seedbed.

Minimum duff depth.--Examination of scattergrams indicated that at preburn duff depths of less than about 0.8 inch $(2 \mathrm{~cm})$, the relationships between duff consumption and the independent variables became erratic. For

Table 3.-Statistics on precision and bias for duff reduction and mineral soil exposure equations shown in the text

\begin{tabular}{|c|c|c|c|c|c|c|c|c|c|c|c|c|}
\hline \multirow[b]{2}{*}{ Equation } & \multirow{2}{*}{$\begin{array}{c}\text { Data } \\
\text { source }^{1}\end{array}$} & \multirow[b]{2}{*}{$\mathbf{N}$} & \multirow[b]{2}{*}{$\mathbf{r}^{2}$} & \multirow[b]{2}{*}{ se } & \multicolumn{4}{|c|}{ Average $(\mathrm{O}-\mathrm{P})^{2}$} & \multicolumn{4}{|c|}{ Root mean square $(\mathbf{O}-\mathrm{P})$} \\
\hline & & & & & $\mathbf{M N}$ & $\mathrm{L}_{\mathrm{f}}$ & $\mathrm{L}_{\mathrm{s}}$ & NI & $\mathbf{M N}$ & $L_{f}$ & $\mathrm{~L}_{s}$ & NI \\
\hline & \multicolumn{12}{|c|}{ Duff Depth Reduction, Inch } \\
\hline 1 & $M N, L_{f}$ & 71 & 0.76 & 0.31 & 0 & 0.03 & -0.67 & -1.26 & 0.30 & 0.38 & 0.74 & - \\
\hline 2 & $\mathrm{MN}$ & 60 & .66 & .34 & 0 & .34 & -.32 & -1.43 & .34 & .70 & .50 & - \\
\hline 3 & $M N, L_{f}$ & 71 & .72 & .33 & -.02 & .14 & -.81 & -.89 & .32 & .39 & .86 & .92 \\
\hline 4 & $\mathrm{MN}$ & 60 & .63 & .36 & 0 & .47 & -.41 & -1.10 & .35 & .76 & .54 & 1.14 \\
\hline 5 & $M N, L_{f}$ & 71 & .58 & .41 & -.04 & .25 & -.40 & -.45 & .35 & .61 & .46 & .52 \\
\hline 6 & $M N, L_{f}, N I$ & 119 & .75 & .31 & .06 & .08 & -.62 & -.06 & .36 & .37 & .68 & .20 \\
\hline \multirow[t]{2}{*}{7} & $M N, L_{f}$ & 71 & .48 & .46 & -.05 & .27 & -.15 & -.59 & .40 & .67 & .27 & .65 \\
\hline & \multicolumn{12}{|c|}{ Duff Depth Reduction, Percent } \\
\hline 8 & $M N, L_{t}$ & 71 & 0.71 & 14.1 & .6 & -3.6 & -25.1 & - & 14.4 & 11.5 & 28.5 & - \\
\hline 9 & $M N, L_{f}$ & 71 & .74 & 13.5 & .6 & -2.6 & -21.6 & - & 13.6 & 11.6 & 27.8 & - \\
\hline 10 & $M N, L_{f}$ & 71 & .69 & 14.7 & -.3 & 1.6 & -30.4 & -49.4 & 14.9 & 11.7 & 33.1 & 51.3 \\
\hline 11 & $\mathrm{MN}, \mathrm{L}$ & 79 & .66 & 15.2 & .7 & 6.6 & -14.1 & - & 14.6 & 12.3 & 19.6 & - \\
\hline 12 & $L_{f}$ & 11 & .58 & 10.5 & -54.7 & -.1 & -18.1 & - & 59.4 & 8.9 & 22.2 & - \\
\hline 13 & $M N, L_{f}$ & 71 & .55 & 17.6 & .6 & -3.2 & -25.5 & -15.1 & 18.2 & 11.7 & 26.9 & 19.3 \\
\hline 14 & $M N, L_{f}, N I$ & 119 & .58 & 16.4 & 1.9 & 4.9 & -16.0 & -3.6 & 19.3 & 11.9 & 18.5 & 12.4 \\
\hline 15 & $M N, L_{f}$ & 71 & .49 & 18.9 & .5 & -2.6 & -15.3 & -20.5 & 19.6 & 12.2 & 17.2 & 23.4 \\
\hline \multirow[t]{2}{*}{16} & $M N, L_{f}$ & 66 & .85 & 9.9 & -2.8 & 13.8 & 2.4 & - & 8.0 & 15.7 & 5.4 & - \\
\hline & \multicolumn{12}{|c|}{ Mineral Soil Exposure, Percent } \\
\hline 17 & $M N, L_{f}$ & 72 & 0.58 & 16.1 & 2.6 & -14.3 & -23.5 & - & 15.7 & 17.0 & 28.3 & - \\
\hline 18 & $L_{f}$ & 11 & .53 & 10.0 & 21.6 & 0 & -10.0 & - & 27.3 & 9.1 & 17.4 & - \\
\hline 19 & $M N, L_{f}$ & 72 & .56 & 16.4 & 1.7 & -8.2 & -30.3 & - & 16.5 & 14.6 & 33.5 & - \\
\hline 20 & $\mathrm{MN}, \mathrm{L}$ & 80 & .55 & 16.7 & 1.8 & -1.4 & -12.2 & - & 17.3 & 9.2 & 16.8 & - \\
\hline 21 & $\mathrm{MN}$ & 61 & .40 & 20.3 & 0 & -18.3 & -31.1 & - & 20.0 & 21.3 & 32.2 & - \\
\hline 22 & $L_{f}$ & 11 & .36 & 11.7 & 22.6 & 0 & -10.6 & - & 30.9 & 10.6 & 14.4 & - \\
\hline 23 & $\mathrm{MN}, \mathrm{L}_{\mathfrak{f}}$ & 66 & .85 & 9.6 & 2.7 & -13.4 & -5.9 & - & 7.9 & 15.2 & 7.5 & - \\
\hline
\end{tabular}

${ }^{1} \mathrm{~L}=$ all Lubrecht data; $\mathrm{L}_{\mathrm{f}}=$ Lubrecht fall; $\mathrm{L}_{\mathrm{s}}=$ Lubrecht spring.

${ }^{2} \mathrm{O}=$ observed average values from burned units; $\mathrm{P}=$ predicted values. 


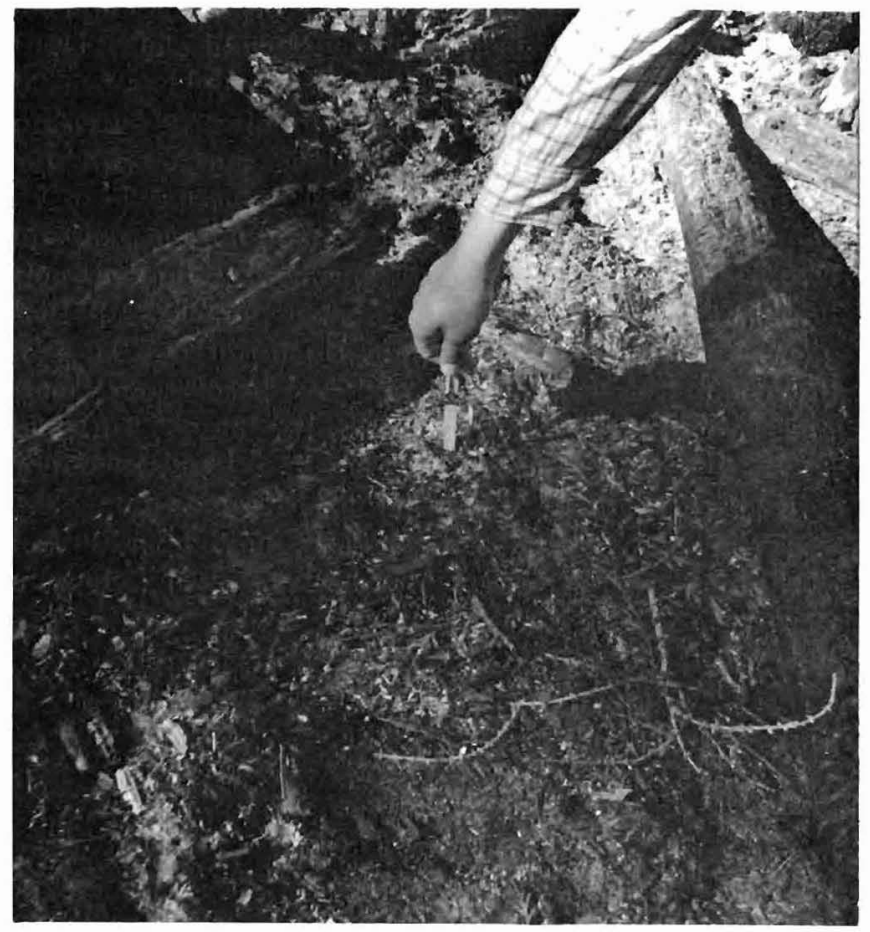

Figure 3.-Measurement of duff reduction along a spike. The head of the spike was flush with the top of the duff before the fire.

example, sometimes plots with very dry duff showed almost total consumption and sometimes very limited consumption. Variability in consumption was more plausible for duff greater than 0.6 to 0.8 inch $(1.5$ to $2 \mathrm{~cm})$ in depth.

In a current study of duff combustion, Frandsen (1983) similarly observed that sustained burnout of duff ceases at an average depth of 0.6 inch $(1.5 \mathrm{~cm})$.

Frandsen (1983) also found that such shallow duff tended to have more incorporated mineral matter, which may retard combustion. Because of the erratic consumption of shallow duff layers, preburn duff depth observations less than 0.6 inch $(1.5 \mathrm{~cm})$ were eliminated from our analyses.

Possible bias in MN data.-Beaufait and others (1977) reported that a bias due to dependence between fuel loadings and fuel moisture content developed at Miller Creek. Plots having heavy downed woody loadings were burned at higher fuel moistures because of a tendency to prescribe-burn the most flammable plots under relatively safe fire-weather conditions.

Correlation analysis and scattergrams suggest that the bias has more influence on downed woody fuel consumption than on duff consumption. Plots of duff depth over NFDR 1,000-hour moisture content show no correlation $(\mathrm{r}=0.026)$. Duff depth and lower duff moisture were weakly correlated $(r=0.17$ ). Duff depth and upper duff moisture content, which we did not include as a variable. were correlated $(\mathrm{r}=0.37)$. Regressions using NFDR 1,000-hour moisture content and 0- to 3 -inch woody fuel loading as dummy variables were attempted to overcome possible bias difficulties. This attempt, however, failed to improve precision or show consistent positive correlations between duff consumption and 0 - to 3 -inch woody fuel loading.

In analysis of small woody fuels, 0 - to $1 / 4$-inch and $1 / 4$ to 1 -inch diameter loadings were positively correlated with 1- and 10-hour timelag moisture contents. However, NFDR 1,000-hour moisture content and 1- to 3-inch woody fuel loadings were not correlated. The extent of possible bias in duff and small woody fuel consumption remains vague, but was probably inconsequential in duff.

Spring fires.-Fires occurring during May and June were considered spring burns. Eight Miller-Newman spring fires were recorded. Scattergrams indicated that Miller-Newman spring and fall fires were from a common population. Nine Lubrecht spring fires were recorded. Our scattergrams agreed with Norum's (1976) previous analysis and indicated that spring and fall fires were from different populations. The Lubrecht spring fires happened during a particularly dry spring following a winter of low snowfall. Because these fires burned during unusual spring weather and indicated a different pattern of fuel consumption than the fall fires, we (like Norum) analyzed the data as separate sets. Analyses including Lubrecht spring fires usually showed reduced precision compared to analyses not including spring fires. In a few cases, however, inclusion of these fires with other data sets improved precision.

Transformation of data.-Nonlinear relationships existed among some variables. To improve linearity, reciprocal and logarithmic transformations of most variables were tried in correlation and regression analysis. Transformations improved some correlations, but the improvements were generally small and not consistent among the data sets. Correlation coefficients between transformed and untransformed variables are displayed in appendix II. Both NFDR 100-hour and 1,000-hour timelag moisture contents were analyzed as independent variables because the moisture timelag of duff may be between the two. They were positively correlated as expected. In regression analysis, the 1,000-hour timelag moisture related more precisely with duff consumption; thus, equations having the 100-hour were not reported.

Lower and upper duff moisture.-Moisture contents were measured for the lower half and upper half of duff at Miller-Newman and Lubrecht, and for the entire duff profile in northern Idaho. An average moisture content (EDM) for the entire duff profile at Miller-Newman and Lubrecht was calculated as the mean moisture content for the lower half and upper half of the duff. Moisture contents for the lower and upper duff layers were positively correlated. Moisture for the lower layer was more highly correlated with dependent variables than was true for the upper layer. In regression analysis, upper duff moisture failed to explain significant variation beyond that explained by lower duff moisture. Thus, the results reported are based on moisture for the lower duff layer and the entire duff profile.

\section{MANAGEMENT APPLICATIONS}

This section contains the best relationships for predicting fuel consumption to help in planning prescribed fires. 
They should apply to a wide range of fuels and cover types. The duff consumption relationships are the most useful because they are reasonably precise and relate to many important fire effects.

The first step in planning is to clearly define the objectives of the fire apart from the purpose for prescribing it. The objectives should specify what the fire itself is to accomplish immediately. These fire objectives basically involve specifying how much organic material should be consumed and what vegetation should be killed or left alive. Constraints on allowing a fire to burn must also be clearly defined. Constraints obviously include control of the fire and may also involve needs to retain some duff and large downed woody material on the burned sites. Once the desired removal of duff and woody material is specified, fuel moisture contents expected to achieve it can be determined from the relationships in this report.

Determining a fire prescription to result in specified amounts of fuel consumption can be viewed as a threestep process:

1. Decide how much fuel should be left on the ground after the fire.

2. Determine the amount of fuel that should be removed.

3. Determine a range in fuel moisture contents for achieving the specified fuel removal.

Steps 1 and 2 require consideration of many factors, including needs for seedbed preparation, fuel hazard reduction, protection of sites to resist erosion, and provision for maintaining desirable nitrogen levels. Needs for duff removal and duff retention may conflict and may require either a compromise on objectives and constraints or the selection of another alternative. The ranges in conditions tabulated below are suitable for application of the predictive relationships reported here.

\section{Conditions}

Average duff depth, inches

Average lower duff moisture, pct

Average entire duff moisture, pct

Forest overstory species

Woody surface fuels

Ignition method

\section{Range}

$$
0.5 \text { to } 4.5
$$

$30 \%$ and greater

$20 \%$ and greater

Best suited to midelevation forests dominated by western larch, Douglas-fir, grand fir, ponderosa pine, lodgepole pine, Engelmann spruce, subalpine fir, and western white pine

Slash and nonslash

Strip head fires, possibly back fires; area ignition untested
Application beyond these conditions could result in large errors. Most of the duff consumption relationships were derived from variable data. Thus, wide limits on reliability of predictions should be kept in mind when predicting duff consumption. Deviations from predicted values are probably influenced primarily by degree of soil disturbance, variation in duff depth and moisture content, and method of ignition. Generally, less consumption than predicted can be expected where logging disturbance is considerable. In contrast, more consumption can be expected where the firing method results in ignition of all surface fuels. The most accurate predictions can be expected where the terrain is uniform and the stands have developed under closed or nearly closed canopies. In prescribed burn units where stand history and microclimate are varied, the area can be stratified and more than one prediction made.

\section{Duff Depth Reduction}

The depth of duff consumed may be used to estimate the actual change in organic matter and nutrients on a site. It also relates to the amount of smoke produced by burning (Ottmar 1984). If seed stored in the forest floor and the rooting depth of plants are known, the depth of duff consumed can be used to evaluate a fire's impact on postburn succession.

Duff depth reduction can be predicted from lower duff moisture content in figure 4. Knowledge of preburn duff depth (DPRE), from either on-site measurements or observations of similar sites, should be utilized in figure 4 for best accuracy. If preburn depth is not known, assume it is 2 inches $(5 \mathrm{~cm})$. This value is close to the average preburn duff depth of this study. It is slightly greater than the average duff depth found over a broad range of cover types in the Northern Rocky Mountains (Brown and See 1981).

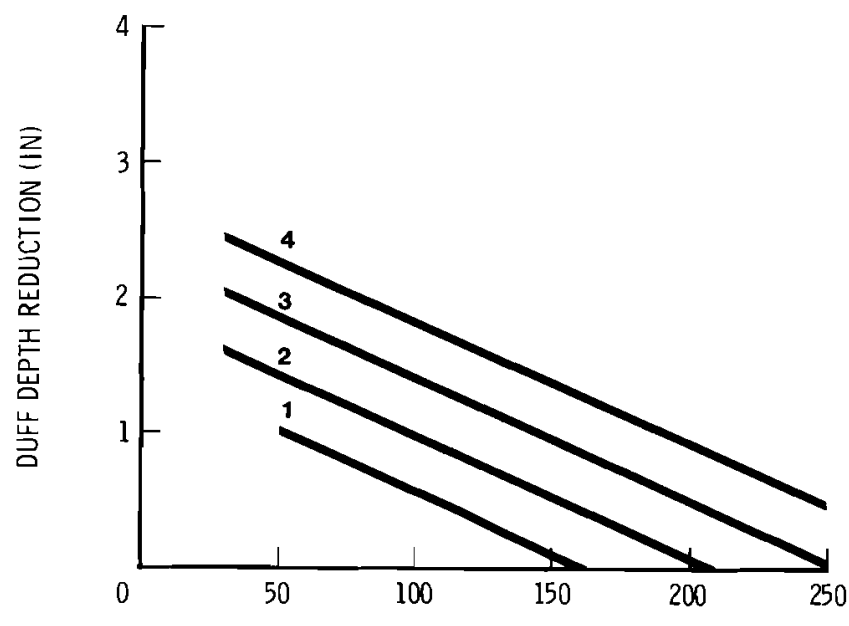

LOWER DUFF MOISTURE (PCT)

Figure 4.-Duff depth reduction versus lower duff moisture content by preburn duff depths (equation 1). One standard error about predictions is 0.3 inch $(0.8 \mathrm{~cm})$. Numbers along curves identify preburn duff depths. 
Moisture content for the entire duff profile can be substituted for lower duff moisture in figure 4 . This will result in duff reduction being overpredicted by an average 0.15 inches $(0.4 \mathrm{~cm})$, an inconsequential amount for practical purposes. Lower duff moisture is recommended for planning duff consumption in prescribed fires because it relates more closely to duff consumption over a wider range of conditions than entire duff moisture. Sometimes, however, it is not practical to separate duff moisture samples into upper and lower strata, particularly when duff depths are 1 inch or less. In such cases or for personal preference, the entire duff moisture can be applied satisfactorily to predicting duff consumption.

The NFDR 1,000-hour moisture content can be used to predict duff depth reduction in figure 5 . If duff depth is unknown, assume a depth of 2 inches $(5 \mathrm{~cm})$. The recommended use of figure 5 is for long-range planning and for judging when duff moisture contents are approaching the prescribed range. Users should be aware of two potential sources of error. First, the NFDR 1,000-hour moisture content is intended to apply to 3- to 6-inch (7.6to 15-cm) logs (Deeming and others 1977), not duff. Log moisture content is dependent primarily on the duration of rain, whereas the duff moisture is more strongly determined by the amount. The second potential source of error is in extrapolating from a weather station to a burn site. If precipitation differs between these locations, predictions of duff consumption will be in error in proportion to the difference in precipitation.

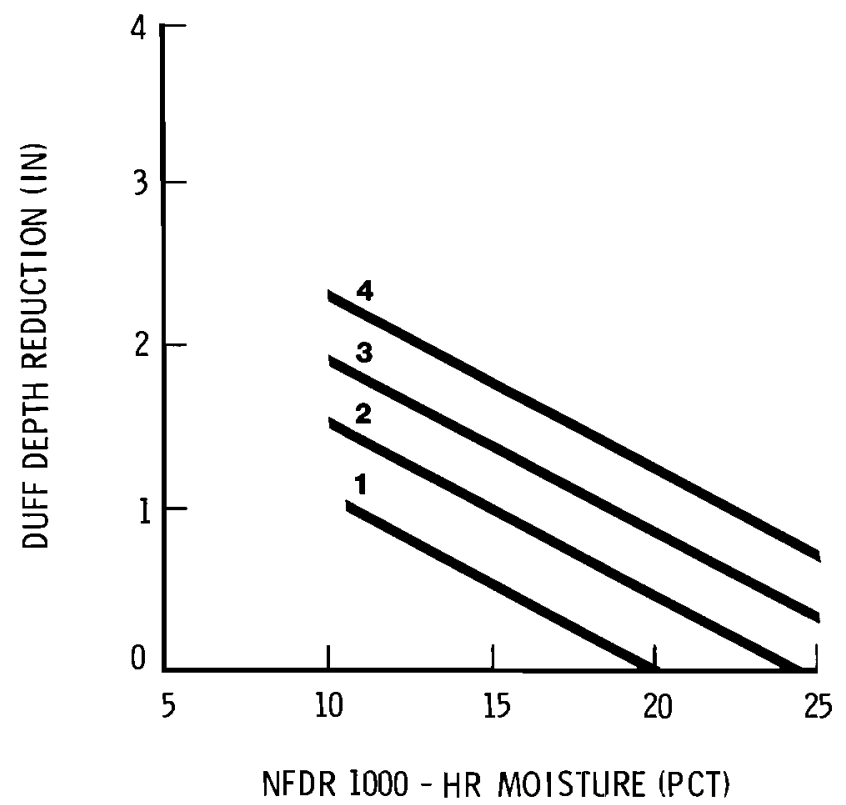

Figure 5.-Duff depth reduction versus NFDR 1,000-hour moisture by preburn duff depths (equation 6). One standard error about predictions is 0.3 inch $(0.8 \mathrm{~cm})$. Num. bers along curves identify preburn duff depths.

\section{Percentage Duff Depth Reduction}

Percentage duff depth reduction is useful because it describes duff consumption independent of duff depth. It is easily understood by others as a prescribed fire objective and is especially suitable for describing the amount of duff to be left unburned for needs such as site protection. Percentage duff reduction can be predicted from lower duff moisture, using figure 6 . It can also be predicted by substituting entire duff moisture for lower duff moisture in figure 6 and adjusting percentage duff reduction as follows:

\section{Entire duff moisture Percent}

Less than 80

80 to 120

Greater than 120

\section{Duff depth reduction Percent}

Subtract 10

Subtract 5

No change
When duff moisture content exceeds 150 percent for either the entire duff profile or the lower layer, duff consumption will remain about 10 to 15 percent. This assumes that a spreading fire is possible. At low duff moistures, 80 to 100 percent consumption can be expected.

The relationship between percentage duff reduction and NFDR 1,000-hour moisture is imprecise and best used as an indicator of when duff moisture may be within prescription. Generally, when NFDR 1,000-hour moisture falls below 25 percent, percentage duff consumption begins increasing. Duff moisture contents are apt to be within prescription when NFDR 1,000-hour moisture is between 10 and 25 percent.

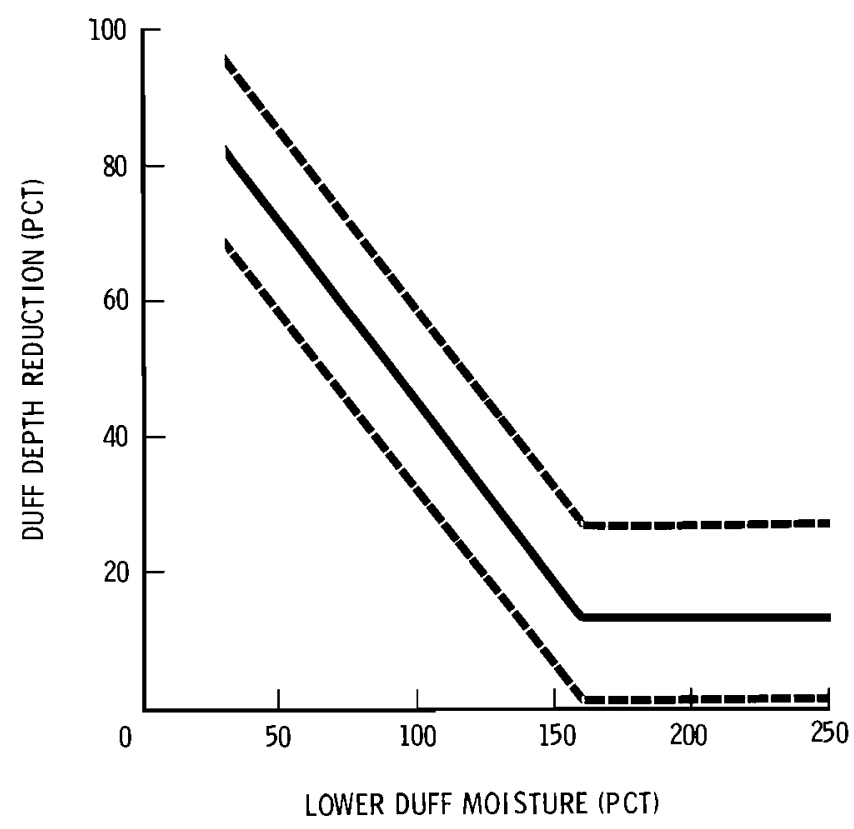

Figure 6. - Percentage duff reduction versus lower duff moisture content (equation 9). The dashed lines are one standard error predic. tion bands. 
The relationship between percentage duff reduction and percentage mineral soil exposure in figure 7 shows how much duff must be removed to expose varying amounts of mineral soil. It can be used, for example, to evaluate whether objectives to create mineral seedbeds are compatible with objectives to retain duff for site protection and as a source of nitrogen.

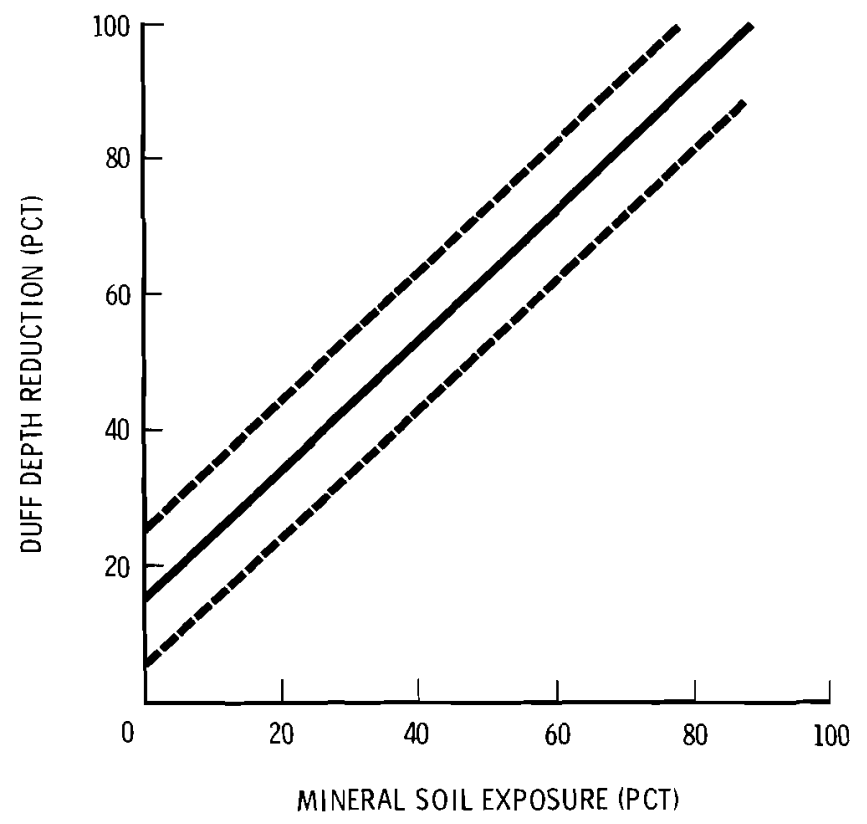

Figure 7.--Percentage duff reduction versus percentage mineral soil exposure (equation 16). The dashed lines are one standard error prediction bands. As a rule of thumb, per. centage duff reduction equals percentage mineral soil exposure plus 15 percent.

\section{Percentage Mineral Soil Exposure}

The predicting of mineral soil exposure is most commonly used for planning use of fire to prepare seedbeds. Percentage mineral soil can be predicted using figure 8 , which offers separate curves for light and moderate to heavy downed woody surface fuels. Light fuels are considered as less than 10 tons per acre $(22.4 \mathrm{t} / \mathrm{ha})$ of 0 - to 3 -inch woody fuel. This includes slash from light cuttings and most nonslash fuels. Moderate to heavy fuels are considered as 10 tons per acre and greater of 0 - to 3-inch downed woody fuel typically from partial cutting and clearcutting activities. Moisture content for the entire duff profile can be substituted for moisture of the lower duff layer when estimating percentage mineral soil for the heavier fuel loading curve in figure 8 , using the following adjustments:
Entire duff moisture Percent

Less than 40

40 to 90

90 to 120

Greater than 120
Mineral soil exposure Percent

Subtract 5

Subtract 10

Subtract 5

No change
The relationship between percentage mineral soil exposure and NFDR 1,000-hour moisture was imprecise as it was for percentage duff reduction. The following guidelines indicate when duff moistures are within prescription:

NFDR 1,000-hour moisture Percent

Greater than 25

10 to 25

Less than 10

\section{Small Woody Fuels}

Generally, percentage consumption of small woody fuels is consistently high when loadings of this material exceed 10 tons/acre $(22.4 \mathrm{t} / \mathrm{ha})$. Consumption is variable but considerably less at lighter loadings. The following tabulation offers as much precision for predicting percentage small woody fuel consumption as is reliable and practical:
Small woody fuel loading Tons/acre
Less than 10
10 and greater
Consumption Percent
Less than 50
70 to 90

The influence of small woody fuel moisture content on percentage consumption appears minor once fire spread is sustained. When quantities of small woody fuels are light, however, percentage consumed depends partly on fuel continuity. Spread of fire is disrupted in sparsely distributed fuels, thus creating unburned fuel patches. In prescribed burning, however, the method of ignition

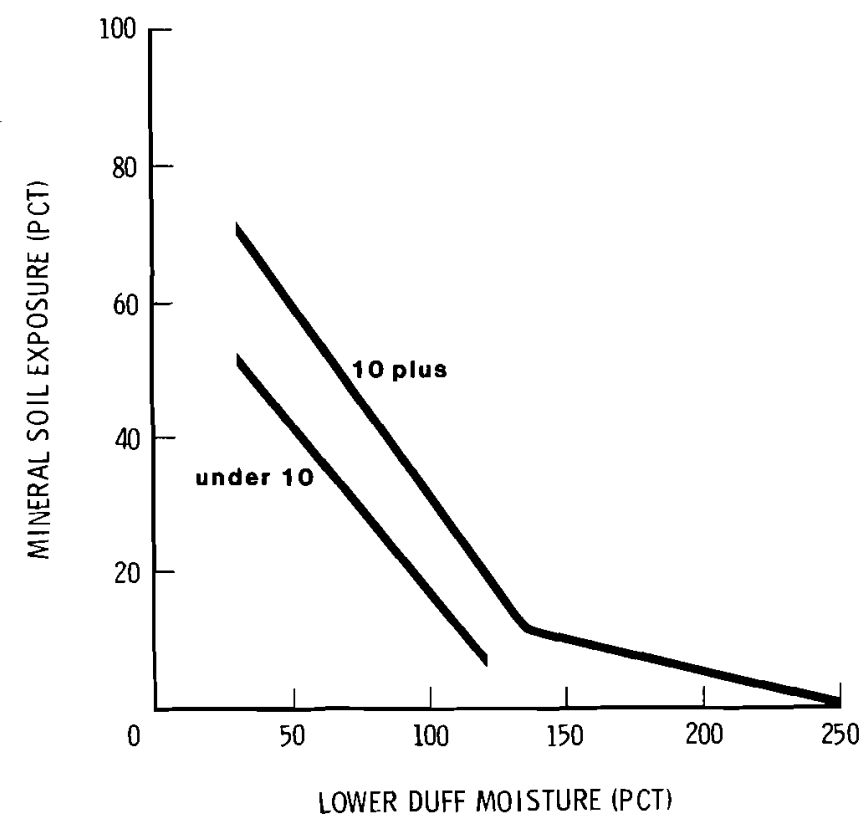

Figure 8.-Percentage mineral soil exposure versus lower duff moisture for 0- to 3-inch downed woody surface fuel loadings of less than 10 tons/acre (equation 18) and 10 tons/acre and greater (equation 17). Standard errors for predictions are 10 and 16 percent, respectively. 
can partially overcome the breakdown in fire spread to increase fuel consumption. Because of this, prediction of percentage consumption in light quantities of small woody fuels may remain imprecise.

\section{Large Woody Fuels}

Although fuel moisture is clearly the primary influence on large woody fuel consumption, quantified guidance for predicting consumption is meager, especially in the Northern Rocky Mountains. Until new information is published, we suggest consulting the following sources of information for guidance:

Recent harvesting slash (Sandberg and Ottmar 1983). - The approximate relationship between large fuel consumption and NFDR 1,000-hour moisture (based on midpoint diameters of size classes) is:

\begin{tabular}{ccc} 
NFDR 1,000-hour & \multicolumn{2}{c}{ Consumption } \\
\cline { 2 - 3 } moisture & $\mathbf{3}$ to $\mathbf{6}$ inches & $\mathbf{6}$ to $\mathbf{9}$ inches \\
Percent & Percent & Percent \\
10 & 100 & 80 \\
15 & 95 & 70 \\
20 & 80 & 55 \\
25 & 65 & 40 \\
30 & 40 & 25
\end{tabular}

Nonslash fuel underburns (Norum 1976).-The following generality is based on the finding that large woody fuel consumption and duff reduction are correlated:

$\begin{array}{cc}\begin{array}{c}\text { Lower duff } \\ \text { moisture }\end{array} & \text { Consumption } \\ \text { Percent } & \text { Percent } \\ 0 \text { to } 40 & 50 \text { to } 100 \\ 40 \text { to } 100 & 10 \text { to } 50 \\ 100+ & \text { Less than } 20\end{array}$

\section{ANALYSIS AND DISCUSSION}

Results of analyses are discussed separately under duff depth reduction, percentage duff depth reduction, and percentage mineral soil exposure. Statistics on precision and bias of the equations in this section are shown in table 3 . In addition, numbers of burn units (N), coefficients of determination $\left(\mathrm{r}^{2}\right)$, and standard errors of regression (se) are shown below each equation. Metric units for all equations are shown in appendix III. When addition of a second independent variable resulted in a significant and meaningful improvement in precision, equations having one and two independent variables are presented.

\section{Duff Depth Reduction (DR)}

The best equations having lower duff moisture (LDM) as an independent variable were:

$$
\begin{aligned}
\mathrm{DR} & =1.028-0.0089 \mathrm{LDM}+0.417 \mathrm{DPRE} \\
(\mathrm{N} & \left.=71, \mathrm{r}^{2}=0.76, \mathrm{se}=0.31\right) \\
\mathrm{DR} & =1.801-0.0079 \mathrm{LDM} \\
(\mathrm{N} & \left.=60, \mathrm{r}^{2}=0.66, \mathrm{se}=0.34\right)
\end{aligned}
$$

The best equations having entire duff moisture (EDM) as an independent variable were:

$$
\begin{aligned}
\mathrm{DR} & =0.8811-0.0096 \mathrm{EDM}+0.439 \mathrm{DPRE} \\
(\mathrm{N} & \left.=71, \mathrm{r}^{2}=0.72, \mathrm{se}=0.33\right) \\
\mathrm{DR} & =1.682-0.0085 \mathrm{EDM} \\
(\mathrm{N} & \left.=60, \mathrm{r}^{2}=0.63, \mathrm{se}=0.36\right)
\end{aligned}
$$

Where duff layers are thin, such as in northern Idaho, it is impractical to separate upper and lower duff for moisture sampling. In these situations entire duff moistures are the most appropriate for characterizing duff. Where duff depth exceeds about 1 inch $(2.5 \mathrm{~cm})$, however, there is a tradeoff between simplicity and precision. Collecting lower duff samples by separating the lower one-half of the duff from the duff and litter above should produce the most precise prediction. In contrast, collecting samples from the entire duff layer avoids the task of separation but may result in a less precise estimate of duff consumption.

Using both duff moisture and preburn duff depth (DPRE) as independent variables produces regression equations that are more precise than those with duff moisture as a single independent variable (compare equations 1 and 2 and equations 3 and 4). For preburn duff depths less than 2 inches and lower duff moistures less than about 50 percent, depth reduced approaches the preburn depth (fig. 4). Examination of plotted data showed that when duff is dry, preburn duff depth and duff depth reduced are highly correlated because dry duff generally burns out well. When damp, such as above about 100 percent moisture content, the correlation is poor; hence, preburn duff depth alone is not a reliable predictor.

Predicted by fire weather indices. - The best equations having NFDR 1,000-hour moisture (TH) as an independent variable were:

$$
\begin{aligned}
\mathrm{DR} & =2.698-0.1035 \mathrm{TH} \\
(\mathrm{N} & \left.=71, \mathrm{r}^{2}=0.58, \mathrm{se}=0.41\right) \\
\mathrm{DR} & =1.773-0.1051 \mathrm{TH}+0.399 \mathrm{DPRE} \\
(\mathrm{N} & \left.=119, \mathrm{r}^{2}=0.75, \mathrm{se}=0.31\right)
\end{aligned}
$$

Although duff probably varies in its time response for drying, the NFDR 1,000-hour moisture correlated reasonably well with duff consumption over the range of depths studied. For regression with NFDR 1,000-hour moisture alone, equation 5 provided the best fit to all data of any combination of data sets. Addition of preburn duff depth to regression equation 6 , improved precision for all data set combinations. Equation 6 is the most robust for application because it is based on the largest range in data. Bias averaged less than 0.08 inches $(2 \mathrm{~mm}$ ) except for Lubrecht spring (table 3). The range in NFDR 1,000-hour moisture ( 7 to 25 percent) for equations 5 and 6 was reasonably large but somewhat limited on the moist end of the scale for extrapolation.

Lower duff moisture content predicted duff consumption with only slightly more precision and less bias than NFDR 1,000-hour moisture, which was surprising because NFDR 1,000-hour moisture is only an indicator of moisture content. The relationship between lower duff moisture and NFDR 1,000-hour moisture (fig. 9) illustrates the possible limitations of relating duff consumption to fire-danger moisture models due to the imprecise 
association between moisture models and duff moisture content. Regression of duff consumption on the Canadian Adjusted Duff Moisture Code (Van Wagner 1974), equation 7 , was slightly less precise than on NFDR 1,000-hour moisture:

$$
\begin{aligned}
& \mathrm{DR}=0.4094+0.0070 \mathrm{ADMC} \\
& \left(\mathrm{N}=71, \mathrm{r}^{2}=0.48, \text { se }=0.46\right)
\end{aligned}
$$

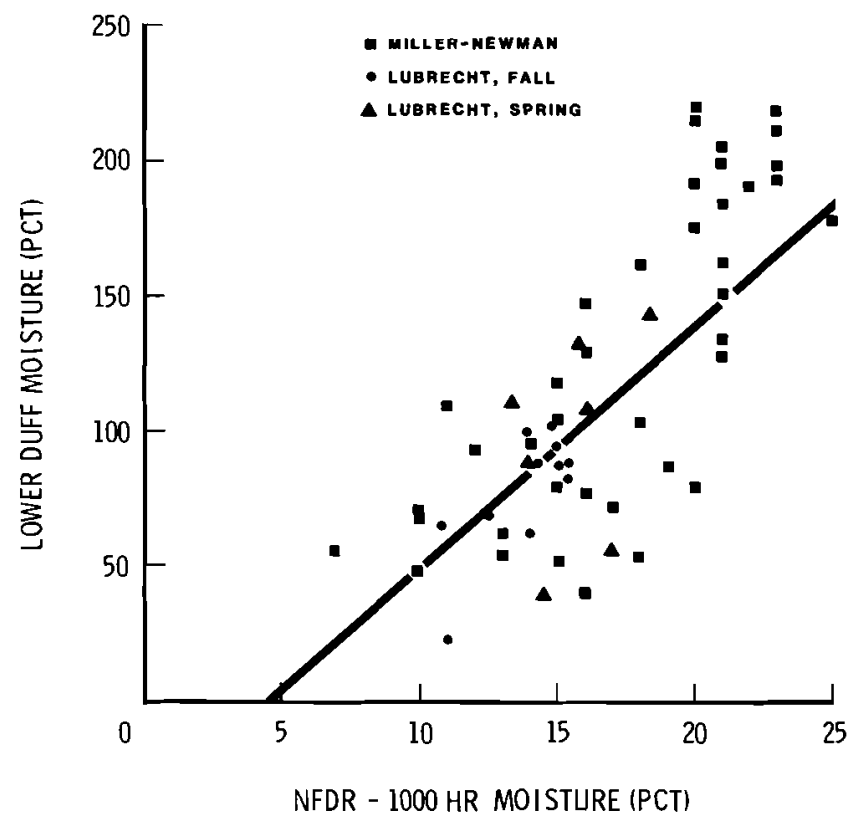

Figure 9.-Lower duff moisture content versus the NFDR 1,000-hour moisture content.

\section{Percentage Duff Depth Reduction (DR\%)}

Predicted by duff moisture.-Prior work by Shearer (1975) and Norum (1977) at Miller Creek and Lubrecht showed similar relationships between percentage duff reduction and lower duff moisture content. Statistics on precision, however, were not furnished. We reexamined this relationship primarily to estimate sampling precision. Scattergrams indicated a curvilinear relationship between percentage duff reduction and lower duff moisture and that the Miller-Newman and Lubrecht fall data could be pooled (fig. 10). The best linear regression fit was:

$$
\begin{aligned}
\mathrm{DR} \% & =87.8-0.390 \mathrm{LDM} \\
(\mathrm{N} & \left.=71, \mathrm{r}^{2}=0.71, \text { se }=14.1\right)
\end{aligned}
$$

High variability in duff consumption at the lower duff moistures made the data difficult to fit. Reciprocal and logarithmic transformations failed to improve fit. Likewise, analysis using MATCHACURVE (Jensen and Homeyer 1970) failed to improve fit over equation 8 . Finally, the following segmented regression improved precision slightly and fit Lubrecht fall data with slightly less bias than equation 8 (table 3 , fig. 3):

$$
\begin{aligned}
\mathrm{DR} \%= & 97.1-0.519 \mathrm{LDM}, \mathrm{LDM} \leq 160 \text { percent } \\
& 13.6, \mathrm{LDM}>160 \text { percent } \\
(\mathrm{N}= & \left.71, \mathrm{r}^{2}=0.74, \text { se }=13.5\right)
\end{aligned}
$$

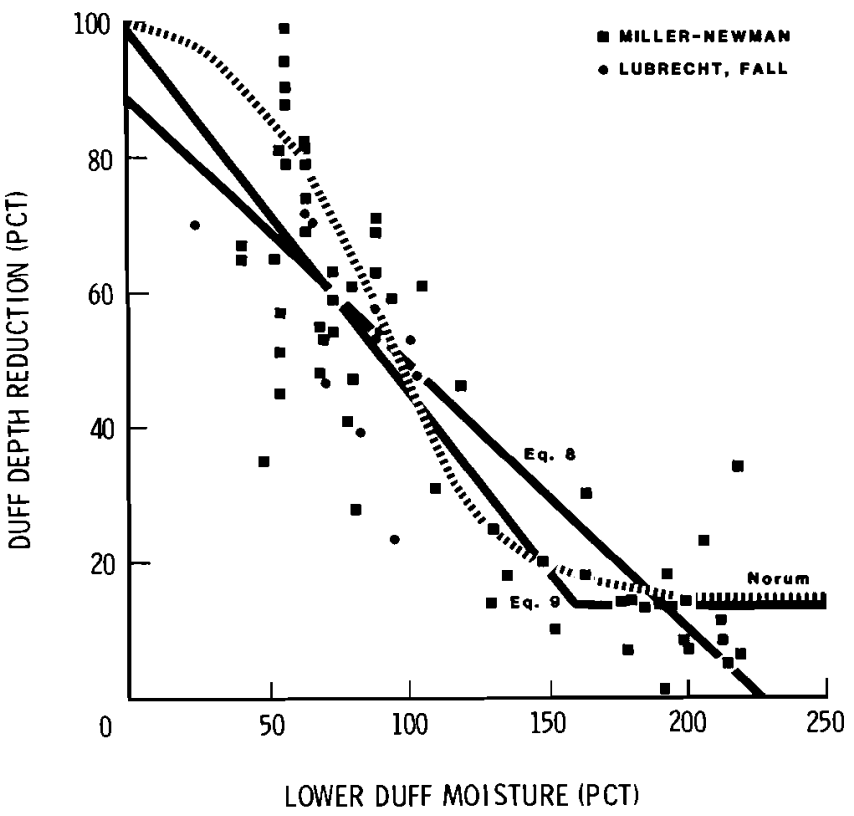

Figure 10.-Percentage duff depth reduction versus lower duff moisture content. Equations 8 and 9 and Norum's (1977) curves are graphed.

The segmented regression is appealing because the data form a knee where consumption levels off, and the regression avoids unreasonable solutions when applied at high moisture contents.

The best equation having entire duff moisture as an independent variable was:

$$
\begin{aligned}
\mathrm{DR} \% & =83.7-0.426 \mathrm{EDM} \\
(\mathrm{N} & \left.=71, \mathrm{r}^{2}=0.69, \text { se }=14.7\right)
\end{aligned}
$$

Influence of surface fuel.-Duration of surface fire should be better than surface fuel consumption as a predictor of duff consumption, because preheating and drying of duff should relate more closely to duration of free-burning fire than to intensity or other fire characteristics. In a practical sense this may be a minor point because woody fuel consumption and duration are probably positively correlated. We were unable to estimate surface fire duration from our data but did examine the significance of 0 - to 1 -inch and 0 - to 3 -inch woody fuel preburn loadings and consumption in regression.

Preburn loadings of the 0- to 3-inch woody fuel (WT3) and the consumed loadings were highly correlated. In the first screening using regression analysis, the preburn loading performed as well as consumed loading in explaining variation. Thus, consumed loading was omitted from later regression analyses because in practice it is more difficult to determine than preburn loading. Generally, 0 - to 3-inch woody fuel was a better predictor than 0- to 1 -inch woody fuel.

The following equation for the Miller-Newman and Lubrecht pooled data shows an influence of surface fuels that is intermediate to equations for Miller-Newman and Lubrecht separately:

$$
\begin{aligned}
\mathrm{DR} \% & =75.8-0.397 \mathrm{LDM}+0.656 \mathrm{WT} 3 \\
(\mathrm{~N} & \left.=79, \mathrm{r}^{2}=0.66, \mathrm{se}=15.2\right)
\end{aligned}
$$


In multiple regression analysis, 0 - to 3 -inch woody fuel was nonsignificant when entered after lower duff moisture for the Miller-Newman data, but was highly significant in the following equation for the Lubrecht data:

$$
\mathrm{DR} \%=70.2-0.384 \mathrm{LDM}+3.72 \mathrm{WT} 3
$$$$
\left(\mathrm{N}=11, \mathrm{r}^{2}=0.58, \mathrm{se}=10.5\right)
$$

Miller-Newman data confirmed Sandberg's (1980) findings that once lower duff moisture was known, woody fuel loading in slash had an inconsequential influence on duff consumption. Perhaps downed woody slash fuel is less influential on duff consumption because much of it is suspended above the duff. In naturally occurring fuels, such as at Lubrecht, much of the woody fuel lies on the litter and duff. Heat transfer between duff and woody fuel would be more efficient and highly correlated. In this situation, burnout of woody fuel would probably support burnout of the duff.

We believe, due to variability in the data, findings of Sandberg (1980), and possible bias in the Miller-Newman data, that the effect of surface fuel consumption on duff consumption remains poorly quantified. Windspeed and shrub load were each regressed on percentage duff reduction after lower duff moisture for combinations of data. These variables were either nonsignificant or inconsequential.

The preliminary duff consumption guideline by Norum (1977), based largely on Lubrecht data, shows a strong influence of surface fuel loading on duff consumption that has not been verified by others. It may be appropriate for naturally occurring fuels but not in slash. Also, for many prescribed burning situations, especially where cutting activities have disturbed the ground, it seems unlikely that duff consumption would approach 100 percent (fig. 10).

Predicted by fire weather indices. - The best equations having NFDR 1,000-hour moisture as an independent variable were:

$$
\begin{aligned}
\mathrm{DR} \% & =114.7-4.20 \mathrm{TH} \\
(\mathrm{N} & \left.=71, \mathrm{r}^{2}=0.55, \mathrm{se}=17.6\right) \\
\mathrm{DR} \% & =111.4-4.69 \mathrm{TH}+0.526 \mathrm{WT} 3 \\
(\mathrm{~N} & \left.=119, \mathrm{r}^{2}=0.58, \mathrm{se}=16.4\right)
\end{aligned}
$$

Prediction from fire weather indices is imprecise, as illustrated by the wide scatter of data in figure 11. Surface fuel loading contributed little to explaining variation in percentage duff reduction and was secondary to NFDR 1,000-hour moisture, as shown by equation 14 and table 3 . A change of 20 tons/acre (45 t/ha) changes percentage duff reduction by only 10 percent.

In an effort to improve the prediction of percentage duff reduction using NFDR 1,000-hour moisture, three sets of data were created by eliminating plots having at least $0.05,0.10$, and 0.25 inches of rain occurring over the past 5 days. This was expected to reduce variability between the NFDR 1,000-hour moisture and duff moisture and hence between NFDR 1,000-hour moisture and duff consumption. The coefficient of determination and standard error terms were improved slightly but not enough to be of practical importance:

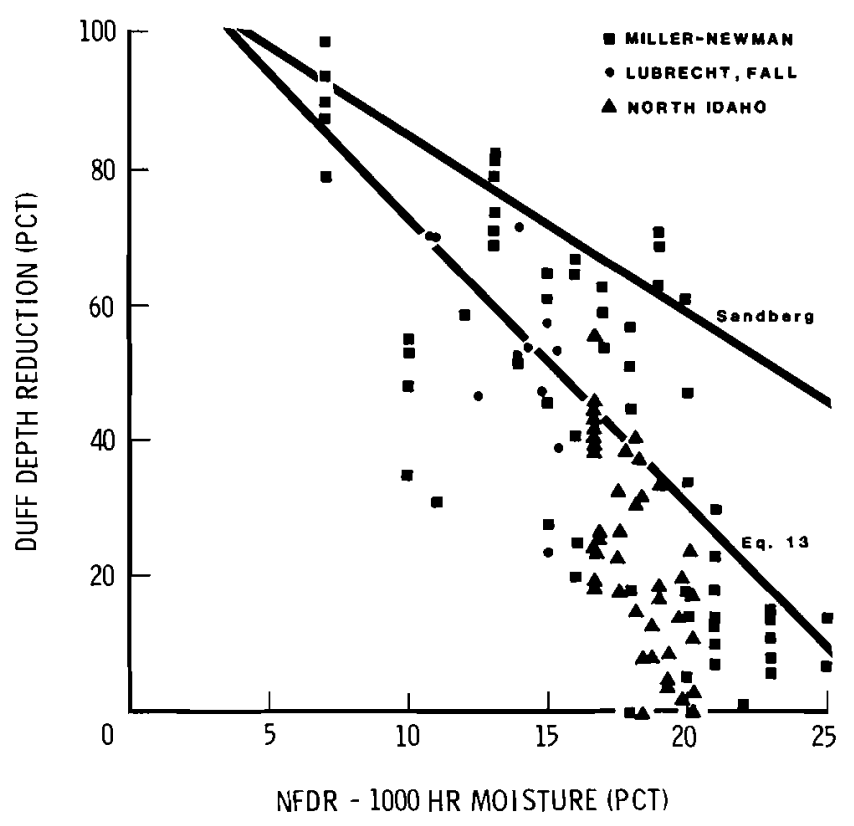

Figure 11.- Percentage duff depth reduction versus NFDR 1,000-hour timelag moisture content. Equation 13 and Sandberg's (1980) curves are graphed.

Data set

Eliminate 0.05 inch

Eliminate 0.10 inch

Eliminate 0.25 inch

All

Similar minor improvements in precision were found for the relationships between duff depth reduction (inches) and NFDR 1,000-hour moisture.

Regression of percentage duff reduction on the Canadian Adjusted Duff Moisture Code, equation 15, was slightly less precise than on NFDR 1,000-hour moisture, equation 13:

$\mathrm{DR} \%=21.2+0.293 \mathrm{ADMC}$

$$
\left(\mathrm{N}=71, \mathrm{r}^{2}=0.49 \text {, se }=18.9\right)
$$

A linear relationship provided the best fit between percentage duff reduction and percentage mineral soil exposure:

$$
\begin{aligned}
\mathrm{DR} \% & =15.2+0.948 \mathrm{M} \% \\
(\mathrm{~N} & \left.=66, \mathrm{r}^{2}=0.85, \text { se }=9.9\right)
\end{aligned}
$$

\section{Percentage Mineral Soil Exposure (M\%)}

The northern Idaho data were omitted from analyses of mineral soil because little of it was exposed by fire and the effect of logging disturbance on mineral soil could not be quantified. Duff spike observations at Miller-Newman and Lubrecht indicated no mineral soil exposure before burning. Logging disturbance did not complicate interpretation of data at these sites.

Predicted by duff moisture.-The best fit for the relationship between percentage mineral soil and lower duff moisture, using pooled data for Miller-Newman and 
Lubrecht (fall), was provided by the following broken line regression (fig. 12):

$$
\begin{aligned}
& \mathrm{M} \%= 80.0-0.507 \mathrm{LDM}, \mathrm{LDM} \leq 135 \text { percent } \\
& 23.5-0.0914 \mathrm{LDM}, \mathrm{LDM}>135 \text { percent } \\
&\left(\mathrm{N}=72, \mathrm{r}^{2}=0.58, \text { se }=16.1\right)
\end{aligned}
$$

The break between regressions fell at 135 percent, which agrees reasonably well with observations by

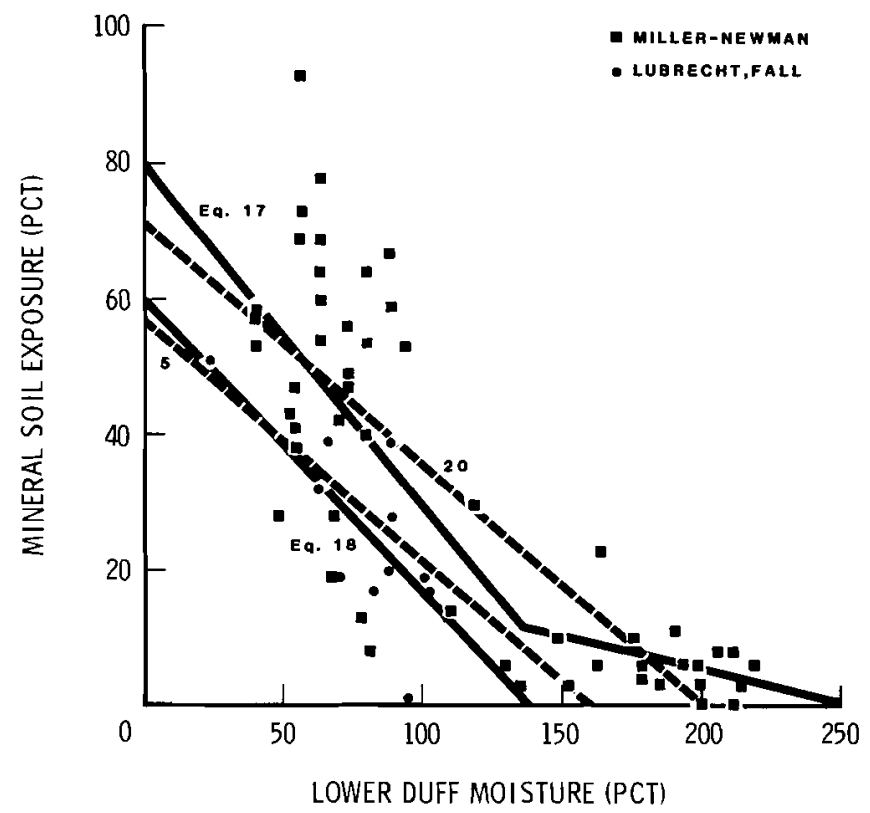

Figure 12. - Percentage mineral soil ex. posure versus lower duff moisture content. Equation 17 is for moderate to heavy slash and equation 18 primarily for nonslash.

Equation 20 is shown for 5 and 20 tons/acre

loadings of 0 - to 3 -inch woody fuel.
Sandberg (1980). Mineral soil exposure varied considerably when moisture content of lower duff was below 135 percent, resulting in imprecise predictions. For nonslash fuels, some improvement in prediction may be possible using equation 18:

$$
\begin{aligned}
\mathrm{M} \% & =60.4-0.440 \mathrm{LDM} \\
(\mathrm{N} & \left.=11, \mathrm{r}^{2}=0.53, \text { se }=10.0\right)
\end{aligned}
$$

Lower duff moisture content in equation 17 and entire duff moisture content in the following equation were nearly equally effective as predictors of mineral soil exposure:

$$
\begin{aligned}
\mathrm{M} \% & =167.4-31.6 \ln \mathrm{EDM} \\
(\mathrm{N} & \left.=72, \mathrm{r}^{2}=0.56, \text { se }=16.4\right)
\end{aligned}
$$

When 0 - to 3 -inch woody fuel was added to regression, the best fitting equation included spring and fall fires:

$$
\begin{aligned}
\mathrm{M} \% & =51.7-0.357 \mathrm{LDM}+0.983 \mathrm{WT} 3 \\
(\mathrm{~N} & \left.=80, \mathrm{r}^{2}=0.55, \mathrm{se}=16.7\right)
\end{aligned}
$$

Equation 20 suggests that woody fuel loading has a greater influence on prediction of percentage mineral soil than on percentage duff reduction. A change of 1 ton/acre causes percentage mineral soil to change 1 percent. Although equation 20 performs reasonably well, the separate functions in figure 8 were suggested for application over equation 20 because they appear to fit the data better when lower duff moistures are greater than 100 percent and less than 30 percent (fig. 12).

Predicted by fire weather indices. - The relationship between percentage mineral soil and NFDR 1,000-hour moisture displayed considerable variation (fig. 13). Observations having low NFDR 1,000-hour moistures were scrutinized to explain why apparently dry duff was poorly consumed; however, explanations were not found.

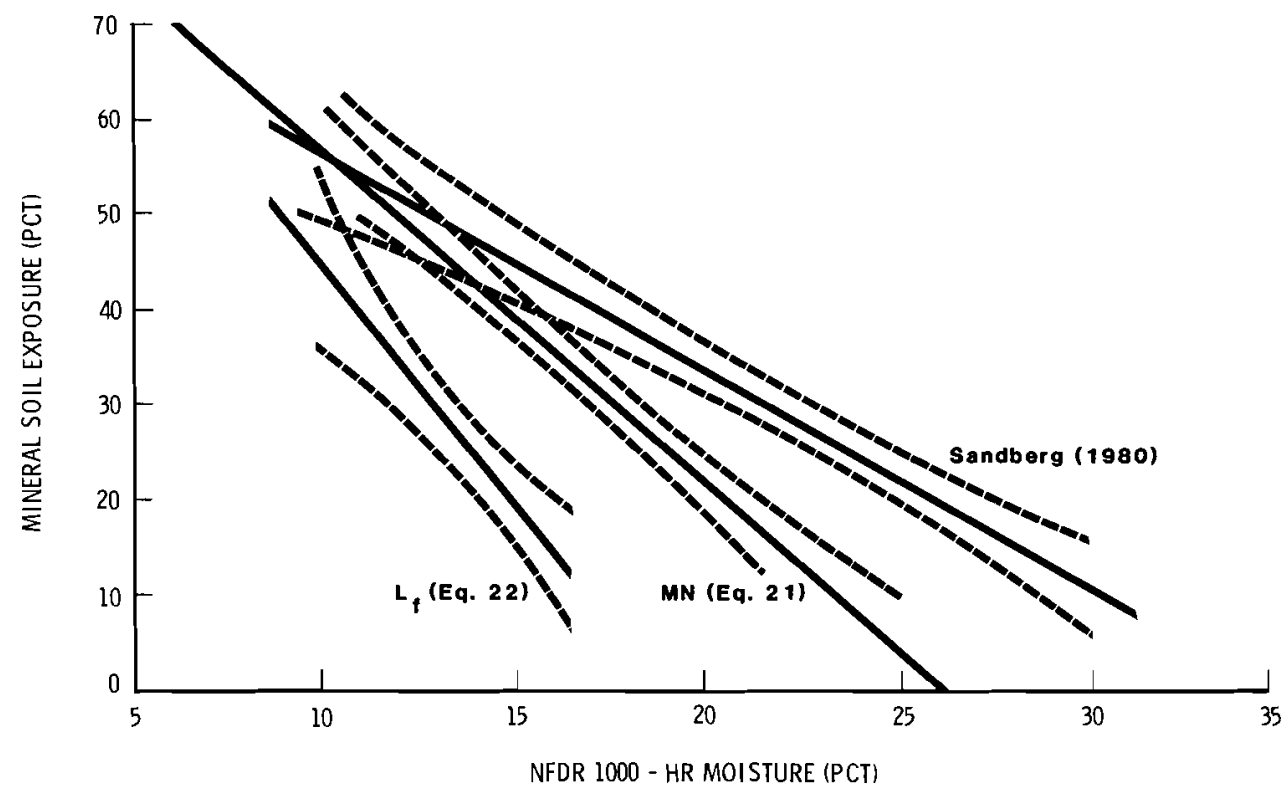

Figure 13. - Percentage mineral soil exposure versus NFDR 1,000-hour moisture content. Confidence bands (broken lines) are for one standard error of the mean. 


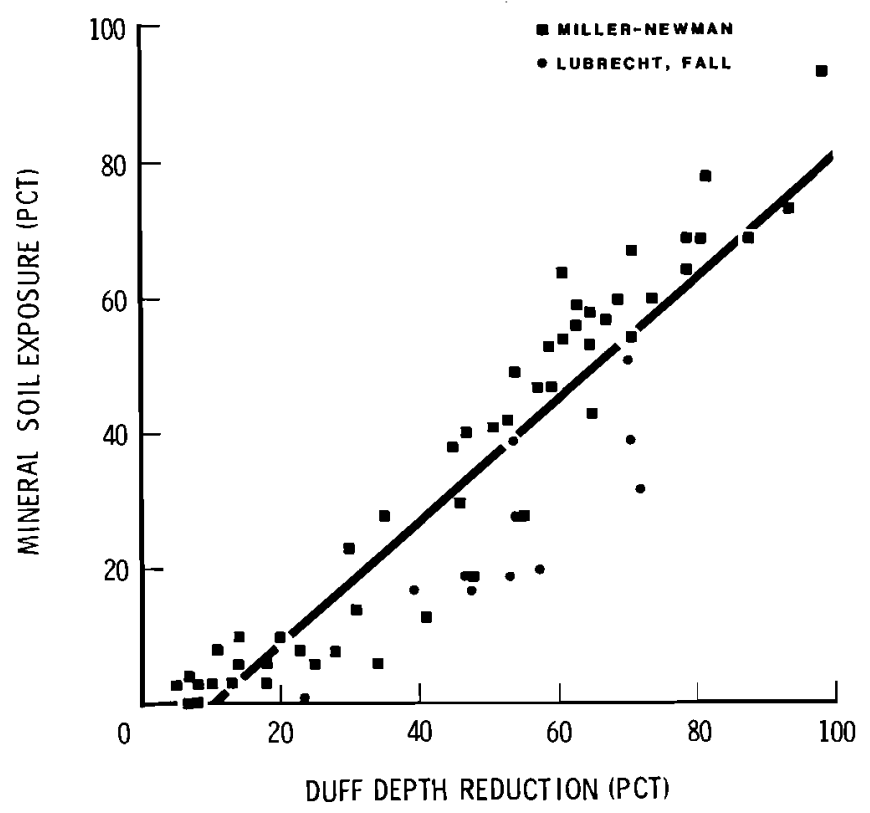

Figure 14.-Percentage mineral soil ex. posure versus percentage duff depth reduction. Equation 23 is graphed.

A function fitted to pooled data appeared unreasonable, thus equations for Miller-Newman and Lubrecht (fall) were derived separately:

$$
\begin{aligned}
\mathrm{M} \% & =93.0-3.55 \mathrm{TH}, \text { Miller-Newman } \\
(\mathrm{N} & \left.=61, \mathrm{r}^{2}=0.40, \text { se }=20.3\right) \\
\mathrm{M} \% & =94.3-4.96 \mathrm{TH}, \text { Lubrecht fall } \\
(\mathrm{N} & \left.=11, \mathrm{r}^{2}=0.36, \mathrm{se}=11.7\right)
\end{aligned}
$$

Addition of 0 - to 3 -inch woody fuel loading to regression analysis resulted in coefficients that were either nonsignificant or of very small consequence. Regression with a stratification of NFDR 1,000-hour moisture serving as dummy variables also failed to improve prediction over regression without dummy variables.

Predicted by percentage duff consumption.-The relationship between percentage mineral soil and percentage duff reduction, which is the reverse of figure 7 , is described by:

$$
\begin{aligned}
\mathrm{M} \% & =-8.98+0.899 \mathrm{DR} \% \\
(\mathrm{~N} & \left.=66, \mathrm{r}^{2}=0.85, \mathrm{se}=9.6\right)
\end{aligned}
$$

This relationship (fig. 14) suggests that burnout of duff proceeds both downward and laterally. If duff burned only downward, little mineral soil would have been exposed until duff was reduced 40 percent or more, and this was not found. The pattern of burnout probably depends on moisture content of duff at microsites and heating from surface fire. Duff moisture content varies considerably over short distances (Hillhouse and Potts 1982), which complicates the burnout processes.

\section{Other Independent Variables}

Reaction intensity (Btu/ft $2 / \mathrm{s}$ ), computed by Rothermel's (1972) fire spread model, was used as an independent variable in regression analysis for seven data set combinations. Reaction intensity was computed from loadings of 0- to 3-inch downed woody material, shrubs, and herbaceous vegetation; thus, it is a measure of surface fire intensity. Reaction intensity was either nonsignificant or weakly correlated with duff depth reduction, percentage duff depth reduction, and percentage mineral soil exposure. Overall, reaction intensity was not a useful predictor, which was not surprising because it represents energy release only from the propagating flame front.

Regression with Duff Moisture Code, Drought Code, and Adjusted Duff Moisture Code of the Canadian Forest Fire Weather Index (Van Wagner 1974) as independent variables showed the ADMC to be the best predictor of duff consumption. In all data sets analyzed, however, the NFDR 1,000-hour moisture provided a slightly more precise relationship with duff consumption than did the ADMC (appendix IV). The NFDR 1,000-hour moisture also was more highly correlated with lower duff moisture than were the Canadian duff moisture codes (appendix IV). This probably explains why it was a more precise predictor of duff consumption.

\section{Testing Equations}

Sandberg's (1980) research in partially cut Douglas-fir slash offered the only opportunity we found to compare findings involving the NFDR 1,000-hour moisture as a predictor. A comparison of equations derived in our study and by Sandberg for predicting percentage duff depth reduction are shown in figure 11 . The differences between our findings and Sandberg's are large enough to be puzzling. Perhaps most of the difference would be eliminated if our data set contained higher observations of NFDR 1,000-hour moisture. A comparison of equations for predicting percentage mineral soil exposure shows reasonable agreement between Miller-Newman slash and Sandberg's slash over a portion of the independent variable (fig. 13). Again, however, the agreement between equations would probably be better if the range in data included larger values of NFDR 1,000-hour moisture. Figure 13 suggests that cutting activity may influence the relationship between mineral soil exposure and the NFDR 1,000-hour moisture.

The relationship between percentage mineral soil and percentage duff reduction reported by Sandberg (1980) agrees closely with ours. He fitted percentage duff reduction as a squared term. Our equation with percentage duff reduction as a squared term resulted in almost identical precision to the untransformed variable in equation 23.

Besides Sandberg's (1980) work in partially cut Douglas-fir slash, already discussed, several other studies on duff consumption were adequately documented for testing accuracy of equations. Predicted values from our equations were compared with values reported from the studies in table 4.

The performance of the equations is summarized in table 5 . The number of tests per equation differed because information required for computing predictions was not equally available for all equations. Equation 2 for predicting duff depth reduction performed well (fig. 15). One observation by Ryan (1982) was underestimated 
Table 4.-Description of studies used to test equations

\begin{tabular}{|c|c|c|c|c|}
\hline Study & Location & $\begin{array}{l}\text { Overstory } \\
\text { type }\end{array}$ & Fuel & $\begin{array}{c}\text { Number } \\
\text { observations }\end{array}$ \\
\hline Harrington (1981) & $\begin{array}{l}\text { Santa Catalina } \\
\text { Mtns., AZ }\end{array}$ & Ponderosa pine & Nonslash & 6 \\
\hline Artley and others (1978) & $\begin{array}{l}\text { Flathead N.F., } \\
\text { MT }\end{array}$ & $\begin{array}{l}\text { Larch/ } \\
\text { Douglas-fir }\end{array}$ & Slash & 6 \\
\hline Little and others (1982) & $\begin{array}{l}\text { Willamette N.F., } \\
\text { OR }\end{array}$ & Douglas - fir & Slash & 2 \\
\hline Ryan (1982) & $\begin{array}{l}\text { Flathead N.F., } \\
\text { MT }\end{array}$ & $\begin{array}{l}\text { Engelmann } \\
\text { spruce, } \\
\text { Douglas-fir, } \\
\text { larch }\end{array}$ & Slash & 2 \\
\hline
\end{tabular}

Table 5. - Comparison of predicted values from selected equations with observed values from other studies. The variables are duff depth reduction (DR), percentage duff depth reduction (DR\%), percentage mineral soil exposure (M\%), lower duff moisture content (LDM), and entire duff moisture content (EDM)

\begin{tabular}{|c|c|c|c|c|c|c|}
\hline Equation & $\begin{array}{l}\text { Dependent } \\
\text { variable }\end{array}$ & $\begin{array}{l}\text { Independent } \\
\text { variable }\end{array}$ & $\begin{array}{l}\text { Number } \\
\text { tests }\end{array}$ & $\begin{array}{l}\text { Average } \\
\text { observed }\end{array}$ & $\begin{array}{l}\text { Average } 1 \\
\text { difference }\end{array}$ & $\begin{array}{c}\text { Average }^{2} \\
\text { percent } \\
\text { difference }\end{array}$ \\
\hline 2 & DR & LDM & 10 & 0.76 inch & 0.12 inch & -4 \\
\hline 4 & DR & EDM & 4 & .73 inch & .35 inch & 63 \\
\hline 8 & DR\% & LDM & 16 & $38.3 \%$ & $-2.8 \%$ & -24 \\
\hline 9 & DR\% & LDM & 16 & $38.3 \%$ & $-1.2 \%$ & -14 \\
\hline 10 & DR\% & EDM & 4 & $21 \%$ & $3.0 \%$ & 39 \\
\hline 17 & $\mathrm{M} \%$ & LDM & 8 & $14.5 \%$ & $6.6 \%$ & 39 \\
\hline 19 & $\mathrm{M} \%$ & EDM & 4 & $14.5 \%$ & $6.4 \%$ & 37 \\
\hline 23 & $M \%$ & DR\% & 8 & $14.5 \%$ & $4.3 \%$ & 21 \\
\hline
\end{tabular}

${ }_{2}^{1}$ Average of observed minus predicted values.

${ }^{2}$ Average of (observed minus predicted)/observed values expressed as percentage. One Ryan observation was omitted because it computed as an infinite difference.

Figure 15. - Comparison of duff depth reduction values observed by Artley and others (1978), Little and others (1982), and Ryan (1982), table 4, with predictions from equation 2.

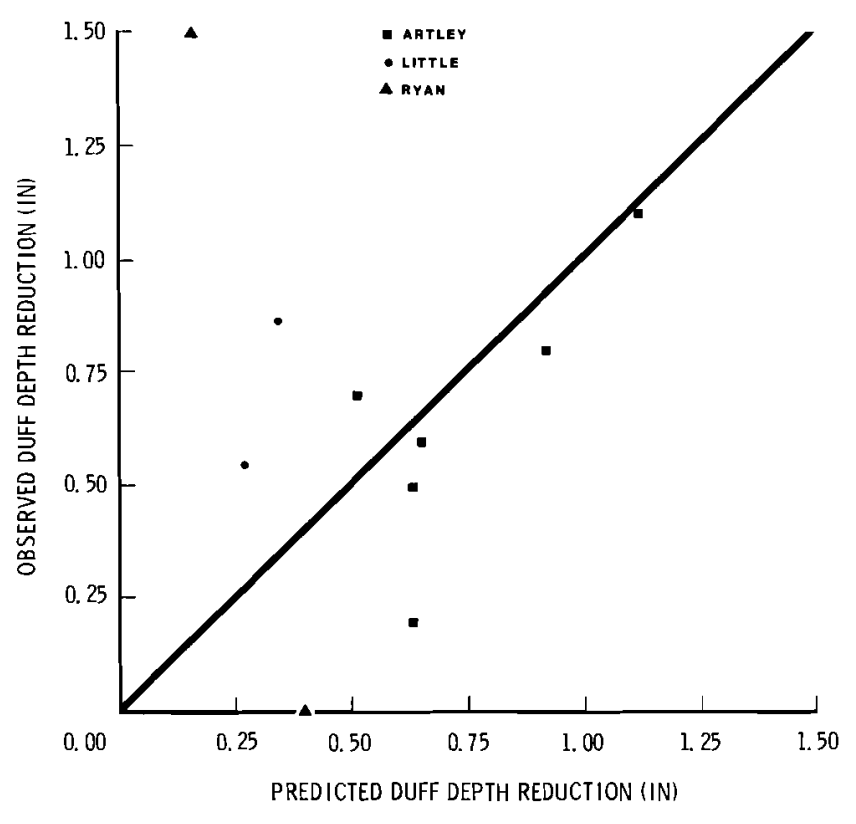


considerably, but not surprisingly, considering that approximately 25 tons/acre $(56 \mathrm{t} / \mathrm{ha})$ of large woody material was also consumed. It seems reasonable to expect increased duff consumption where burnout of large quantities of downed woody fuels provides prolonged heating of duff. Equation 9 for predicting percentage duff depth reduction performed well over a wide range (fig. 16). Particularly interesting was the close agreement between predictions and Harrington's (1981) observations in ponderosa pine. In contrast, the northern Idaho ponderosa pine was difficult to predict using any function. The reason for the disparity in fit is probably due in part to logging disturbance. Harrington's (1981) ponderosa pine stands were undisturbed, whereas the northern Idaho stands had been selectively logged. Possibly another difference is due to a greater preburn duff depth in Harrington's stands compared to northern Idaho where preburn duff depth was marginal for consistent combustion under any conditions.

Overall, the equations performed well. Most differences between observed and predicted values were within one standard error of the mean of the tested equations. These tests lend confidence to use of the equations over the broad range of conditions suggested in the section on Management Applications.

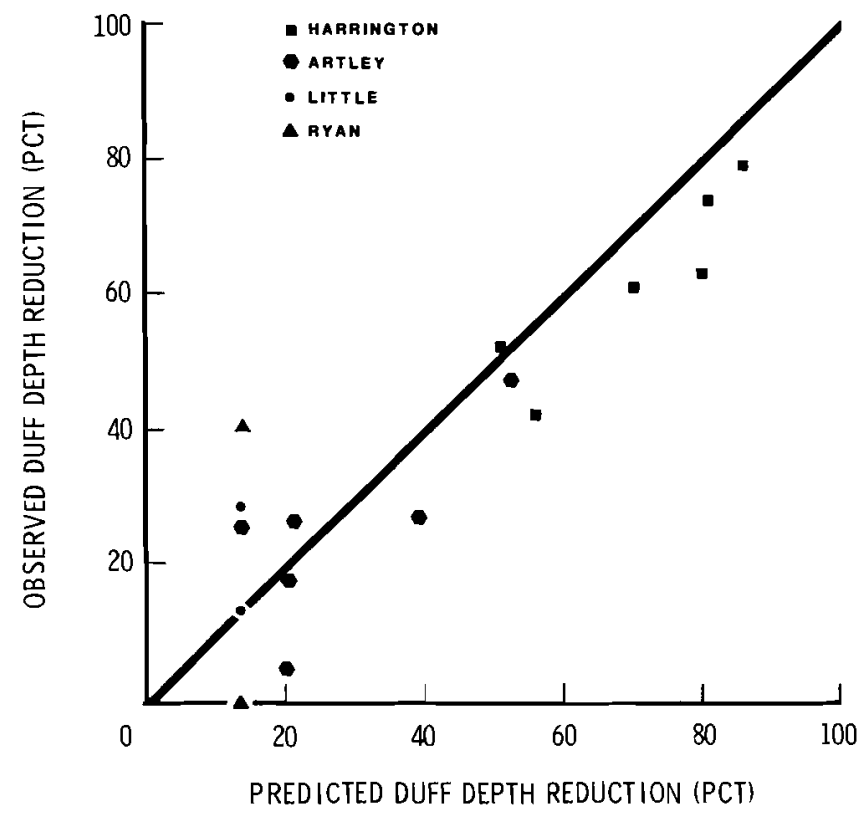

Figure 16.-Comparison of duff depth reduction values observed by Artley and others (1978), Harrington (1981), Little and others (1982), and Ryan (1982), table 4, with predictions from equation 9 .

\section{Small Woody Fuels}

Absolute consumption.-As also reported by Norum (1976) and Beaufait and others (1977), amount of fuel consumed was strongly dependent on fuel loading before burning, table 6 . Other independent variables analyzed were preburn loadings of shrubs, herbaceous vegetation, litter, and combinations of these; moisture content variables, windspeed, foliage remaining on slash, reaction intensity, and ignition method. All independent variables were either nonsignificant or contributed little to the consumption model beyond the contribution of preburn loading.

Percentage consumption.-Percentage consumption was weakly correlated with all independent variables studied. Even fuel moisture content, which strongly affects combustion, was a weak, often illogically correlated predictor, possibly because of bias in the Miller-Newman data. The limited moisture content measurements taken there prior to burning were highly variable and may have masked any true relationship between fuel consumption and moisture content.

A trend in percentage consumption, however, did appear (table 7). For moderate to heavy slash (MN), percentage consumption was uniformly high at 86 percent for 0 - to 1 -inch and 81 percent for 0 - to 3 -inch woody fuels. For light woody fuels (NI and L), percentage consumption varied substantially and averaged 48 percent for 0- to 1-inch and 46 percent for 0 - to 3 -inch. Based on the range in data (table 2), a high percentage consumption can be expected for 0 - to 3 -inch preburn loadings greater than about 10 tons/acre and variable but less consumption for loadings under about 10 tons/acre. This is consistent with a state-of-knowledge review by Martin and others (1979) who reported that slash consumption in clearcuts averaged 70 to 90 percent for small woody fuels. Observations in nonslash fuels from the Western United States varied considerably.

\section{Large Woody Fuels}

Consumption of large woody fuels, like small woody fuels, related closely to preburn fuel loadings. Lower duff moisture content and the NFDR 1,000-hour moisture entered as second independent variables were either nonsignificant or illogically correlated. The best equation based on Lubrecht was:

CWTLG $=-2.7+0.79$ WTLG

$$
\left(\mathrm{N}=20, \mathrm{r}^{2}=0.72, \mathrm{se}=6.64\right)
$$

Both absolute and percentage consumption for the Lubrecht data were weakly and inconclusively correlated with NFDR 1,000-hour moisture and lower duff moisture. The relationship between percentage consumption and large fuel load was also vague. Plotted northern Idaho data revealed a lack of relationships among percentage consumption and the independent variables (including TH, WTLG, and WT3). Due to this and the narrow range in large fuel loadings, further analyses were not attempted. 
Table 6. - Equations for consumption of $0-$ to 1 -inch (CWT1) and $0-$ to 3 -inch (CWT3) downed woody fuels as functions of preburn loading of 0 - to 1 -inch (WT1) and 0 - to 3 -inch (WT3) downed woody fuels

\begin{tabular}{|c|c|c|c|c|c|c|c|}
\hline $\begin{array}{l}\text { Equation } \\
\text { number }\end{array}$ & Data source & $r^{2}$ & se & $\frac{100 \text { (se) }}{y}$ & n & $\begin{array}{l}\text { Range in } \\
\text { preburn } \\
\text { loading }\end{array}$ & Equations \\
\hline & & & Tons / acre & & & Tons / acre & \\
\hline $\begin{array}{l}24 \\
25\end{array}$ & $\begin{array}{l}\text { Miller - Newman } \\
\text { Miller-Newman }\end{array}$ & $\begin{array}{r}0.94 \\
.82\end{array}$ & $\begin{array}{l}0.464 \\
2.008\end{array}$ & $\begin{array}{r}7.6 \\
12.6\end{array}$ & $\begin{array}{l}65 \\
65\end{array}$ & $\begin{array}{r}3.44-14.80 \\
12.84-35.80\end{array}$ & $\begin{array}{l}\text { CWT1 }=0.195+0.831 \text { WT1 } \\
\text { CWT3 }=-1.24+0.873 \text { WT3 }\end{array}$ \\
\hline $\begin{array}{l}26 \\
27\end{array}$ & $\begin{array}{l}\text { Lubrecht } \\
\text { Lubrecht }\end{array}$ & $\begin{array}{l}.76 \\
.75\end{array}$ & $\begin{array}{l}.198 \\
.831\end{array}$ & $\begin{array}{l}44.2 \\
64.0\end{array}$ & $\begin{array}{l}20 \\
20\end{array}$ & $\begin{array}{r}.55-2.13 \\
1.33-7.68\end{array}$ & $\begin{array}{l}\text { CWT1 }=-0.496+0.920 \text { WT1 } \\
\text { CWT3 }=-1.751+0.925 \text { WT3 }\end{array}$ \\
\hline $\begin{array}{l}28 \\
29\end{array}$ & $\begin{array}{l}\text { Northern Idaho } \\
\text { Northern Idaho }\end{array}$ & $\begin{array}{l}.94 \\
.93\end{array}$ & $\begin{array}{l}.363 \\
.415\end{array}$ & $\begin{array}{l}53.8 \\
52.6\end{array}$ & $\begin{array}{l}48 \\
48\end{array}$ & $\begin{array}{l}.03-10.27 \\
.10-11.06\end{array}$ & $\begin{array}{l}\text { CWT1 }=-0.278+0.926 \text { WT1 } \\
\text { CWT3 }=-0.396+0.918 \text { WT3 }\end{array}$ \\
\hline $\begin{array}{l}30 \\
31\end{array}$ & $\begin{array}{l}\text { All studies } \\
\text { All studies }\end{array}$ & $\begin{array}{l}.98 \\
.97\end{array}$ & $\begin{array}{r}.416 \\
1.503\end{array}$ & $\begin{array}{l}12.6 \\
18.2\end{array}$ & $\begin{array}{l}133 \\
133\end{array}$ & $\begin{array}{l}.03-14.80 \\
.10-35.80\end{array}$ & $\begin{array}{l}\text { CWT1 }=-0.269+0.890 \text { WT1 } \\
\text { CWT3 }=-0.670+0.845 \text { WT3 }\end{array}$ \\
\hline
\end{tabular}

Table 7.-Preburn and consumed loadings for $0-$ to $1-$ inch and $0-$ to 3 -inch downed woody fuels

\begin{tabular}{|c|c|c|c|c|c|c|}
\hline \multirow[b]{2}{*}{ Fuel } & \multicolumn{2}{|c|}{ Mean } & \multicolumn{2}{|c|}{ Standard deviation } & \multicolumn{2}{|c|}{$\begin{array}{c}\text { Coefficient of } \\
\text { variation }\end{array}$} \\
\hline & MN & L, NI & MN & L, NI & $\mathrm{MN}$ & L, NI \\
\hline $0-$ to 1 -inch load & & & & & \multicolumn{2}{|c|}{.... Percent .... } \\
\hline Preburn, tons/acre & 7.13 & 1.03 & 2.29 & 1.30 & 32 & 126 \\
\hline Consumed, tons/acre & 6.12 & .61 & 1.96 & 1.25 & 32 & 205 \\
\hline Consumed, percent & 86.2 & 48.1 & 7.4 & 35.4 & 8.6 & 74 \\
\hline \multicolumn{7}{|l|}{$0-$ to 3 -inch load } \\
\hline Preburn, tons/acre & 19.68 & 1.88 & 4.88 & 1.84 & 25 & 98 \\
\hline Consumed, tons/acre & 15.94 & .94 & 4.70 & 1.58 & 30 & 168 \\
\hline Consumed, percent & 80.6 & 45.5 & 10.6 & 33.3 & 13 & 73 \\
\hline
\end{tabular}

Percentage consumption from diameter reduction.Sandberg and Ottmar (1983) developed a method of estimating percentage volume reduction based on the relationship between diameter reduction and NFDR 1,000-hour moisture. The relationship was derived from experimental burns in cable-yarded logging slash.

Although their method was based on slash, we tested it using Norum's nonslash Lubrecht data. Predicted unit consumption was computed using root-mean-squared diameter and NFDR 1,000-hour moisture in their algorithm (Sandberg and Ottmar 1983). Observed values were percentage consumption unit averages. The model substantially underpredicted percentage consumption as shown in the following tabulation of averages:

$\begin{array}{lccc} & \text { Observed } & \text { Predicted } & \text { Difference } \\ \text { Mean } & 64 & 28 & 36 \\ \text { Range } & 0 \text { to } 99 & 16 \text { to } 50 & -25 \text { to } 80\end{array}$

The underprediction is probably due to a high degree of rot in the fuels at Lubrecht and perhaps more contact between fuel pieces and the forest floor. At Lubrecht, 85 percent of the large fuels were classed as rotten (can be kicked apart with the foot). Rotten fuels were excluded from Sandberg and Ottmar's analysis. This may explain the greater than predicted consumption at Lubrecht, because burnout of rotten fuel should be more complete than sound fuel. Contact with a smoldering forest floor would also enhance burnout of large woody pieces. Fuels in place for long periods such as the naturally accumulated ones at Lubrecht would normally have more contact with duff than logging slash.

Sandberg and Ottmar's model was further tested using two slash fires (Ryan 1982). Results were a small overprediction (8 percent) for sound fuel and a large underprediction (42 percent) for rotten fuel. These tests certainly indicate that adjustments to Sandberg and Ottmar's model are needed if it is applied to rotten large woody fuels. 


\section{CONCLUSIONS}

This paper provides land managers a quantitative means of predicting duff and woody fuel consumption that can be especially useful in planning prescribed fires. Tests of the duff consumption relationships against other data suggest wide application is possible. The predictions should be reasonably accurate where duff is continuous and averages more than 0.5 inch $(1.3 \mathrm{~cm})$ deep. Application of results is not recommended in open stands where duff is discontinuous.

Duff moisture content was by far the most influential variable on duff consumption. Loadings of small woody fuels also influenced duff consumption but to a lesser extent. Quantification of this influence remains poorly understood. The NFDR 1,000-hour moisture related more closely to duff consumption than did the Canadian duff moisture codes. The NFDR 1,000-hour moisture should be helpful for developing fire prescriptions. The relationship between percentage mineral soil exposure and percentage duff reduction indicates that duff consumption involves both downward and lateral movement of the combustion interface. Consumption of small woody fuels can be explained simply as most of these fuels are consumed (80 to 90 percent) wherever fire spreads.

To improve knowledge for predicting and understanding fuel consumption, the primary factors influencing large fuel burnout on a practical area basis need to be identified and their relationships to consumption quantified. The relationships between duff consumption, logging disturbance, and consumption of small and large woody fuels need better definition. The need for more precise knowledge to predict duff consumption will grow as future utilization leaves less woody surface fuel to support fire and as prescribed fire objectives become more closely tied to integrated land management objectives.

\section{REFERENCES}

Albini, Frank A. Estimating wildfire behavior and effects. General Technical Report INT-30. Ogden, UT: U.S. Department of Agriculture, Forest Service, Intermountain Forest and Range Experiment Station; 1976. $92 \mathrm{p}$.

Artley, Donald K.; Shearer, Raymond C.; Steele, Robert $\mathrm{V}$. Effects of burning moist fuels on seedbed preparations in cutover western larch forests. Research Paper INT-211. Ogden, UT: U.S. Department of Agriculture, Forest Service, Intermountain Forest and Range Experiment Station; 1978. $14 \mathrm{p}$.

Bakken, Stephen; Neuenschwander, Leon F. Prescribed burning guidelines for ponderosa pine in northern Idaho. Final Report Cooperative Agreement with U.S. Department of Agriculture, Forest Service, and the University of Idaho, Supplement 91 . On file at the Northern Forest Fire Laboratory, Drawer G, Missoula, MT 59806; 1981. 120 p.

Beaufait, William R.; Hardy, Charles E.; Fischer, William C. Broadcast burning in larch-fir clearcuts: the Miller Creek-Newman Ridge study. Research Paper INT-175. Ogden, UT: U.S. Department of Agriculture,
Forest Service, Intermountain Forest and Range Experiment Station; $1977.53 \mathrm{p}$.

Brown, James $\mathrm{K}$. Handbook for inventorying downed woody material. General Technical Report INT-16. Ogden, UT: U.S. Department of Agriculture, Forest Service, Intermountain Forest and Range Experiment Station; 1974. 24 p.

Brown, James K.; Roussopoulos, Peter J. Eliminating biases in the planar intersect method for estimating volumes of small fuels. Forest Science. 20(4): 350-356; 1974.

Brown, James K.; See, Thomas E. Downed dead woody fuel and biomass in the Northern Rocky Mountains. General Technical Report INT-117. Ogden, UT: U.S. Department of Agriculture, Forest Service, Intermountain Forest and Range Experiment Station; 1981. $48 \mathrm{p}$.

Chrosciewicz, Z. Slash and duff reduction by burning on clearcut jack pine sites in southwestern Manitoba. Information Report NOR-X-199. Edmonton, AB: Canadian Forestry Service; 1978a. 11 p.

Chrosciewicz, Z. Slash and duff reduction by burning on clearcut jack pine sites in central Saskatchewan. Information Report NOR-X-200. Edmonton, AB: Canadian Forestry Service; 1978b. 12 p.

DeByle, Norbert V. Clearcutting and fire in the larch/Douglas-fir forests of western Montana-a multifaceted research summary. General Technical Report INT-99. Ogden, UT: U.S. Department of Agriculture, Forest Service, Intermountain Forest and Range Experiment Station; 1981. 73 p.

Deeming, John E.; Burgan, Robert E.; Cohen, Jack D. The National Fire-Danger Rating System - 1978. General Technical Report INT-39. Ogden, UT: U.S. Department of Agriculture, Forest Service, Intermountain Forest and Range Experiment Station; 1977. $63 \mathrm{p}$.

Fosberg, Michael A. Drying rates of heartwood below fiber saturation. Forest Science. 16(1): 57-63; 1970.

Frandsen, William H. 1983. Unpublished research results on file at: U.S. Department of Agriculture, Forest Service, Intermountain Forest and Range Experiment Station, Northern Forest Fire Laboratory, RWU 2103 files, Missoula, MT.

Harrington, Michael G. Preliminary burning prescriptions for ponderosa pine fuel reductions in southwestern Arizona. Research Note RM-402. Fort Collins, CO: U.S. Department of Agriculture, Forest Service, Rocky Mountain Forest and Range Experiment Station; 1981. 7 p.

Hillhouse, Margaret I.; Potts, Donald F. Duff reduction in site preparation. In: Baumgartner, David M., ed. Site preparation and fuels management on steep terrain: proceedings of a symposium; 1982 February 15-17; Spokane, WA. Pullman, WA: Washington State University, Cooperative Extension; 1982: 67-73.

Jensen, Chester E.; Homeyer, Jack W. Matchacurve-1 for algebraic transforms to describe sigmoid- or bellshaped curves. Ogden, UT: U.S. Department of Agriculture, Forest Service, Intermountain Forest and Range Experiment Station; 1970. 22 p. 
Little, Susan N.; Ward, Franklin R.; Sandberg, D. V. Duff reduction caused by prescribed fire on areas logged to different management intensities. Research Note PNW-397. Portland, OR: U.S. Department of Agriculture, Forest Service, Pacific Northwest Forest and Range Experiment Station; 1982. 8 p.

Martin, R. E. [and others]. Effects of fire on fuels. General Technical Report WO-13. Washington, DC: U.S. Department of Agriculture, Forest Service; 1979. $67 \mathrm{p}$.

Norum, R. A. Preliminary guidelines for prescribed burning under standing timber in western larch/Douglas-fir forests. Research Note INT-229. Ogden, UT: U.S. Department of Agriculture, Forest Service, Intermountain Forest and Range Experiment Station; 1977. $15 \mathrm{p}$.

Norum, Rodney A. Fire intensity-fuel reduction relationships associated with understory burning in larch/Douglas-fir stands. In: Proceedings Tall Timbers fire ecology conference No. 14 and Intermountain Fire Research Council fire and land management symposium; October 1974; Missoula, MT. Talahassee, FL: Tall Timbers Research Station; 1976: 559-572.

Ottmar, Roger D. Predicting fuel consumption by fire stages to reduce smoke from slash fires. In: Proceedings 1983 annual meeting, Northwest Forest Fire Council; 1983 November 21-22; Olympia, WA. Olympia, WA: Northwest Forest Fire Council; 1984: 87-106.

Rothermel, Richard C. A mathematical model for predicting fire spread in wildland fuels. Research Paper INT-115. Ogden, UT: U.S. Department of Agriculture, Forest Service, Intermountain Forest and Range Ex. periment Station; 1972. $40 \mathrm{p}$.

Ryan, Kevin C. Burning for site preparation on steepslope helicopter- logged clearcuts in northwestern Monana. In: Baumgartner, David M., ed. Site prepa- ration and fuels management on steep terrain; proceedings of a symposium; 1982 February 15-17, Spokane, WA. Pullman, WA: Washington State University, Cooperative Extension; 1982: 25-33.

Sandberg, D. V.; Ottmar, R. D. Slash burning and fuel consumption in the Douglas-fir subregion. In: Seventh conference on fire and forest meteorology symposium proceedings; April 1983; Fort Collins, CO. Fort Collins, CO: American Meteorological Society; 1983: 90-93.

Sandberg, David V. Duff reduction by prescribed underburning in Douglas-fir. Research Paper PNW-272. Portland, OR: U.S. Department of Agriculture, Forest Service, Pacific Northwest Forest and Range Experiment Station; 1980. 18 p.

Shearer, Raymond C. Seedbed characteristics in western larch forests after prescribed burning. Research Paper INT-167. Ogden, UT: U.S. Department of Agriculture, Forest Service, Intermountain Forest and Range Experiment Station; 1975. 26 p.

Shearer, Raymond C. Personal communication. 1983. Missoula, MT: U.S. Department of Agriculture, Forest Service, Intermountain Forest and Range Experiment Station.

U.S. Department of Agriculture, Forest Service. National fire-danger rating handbook. Forest Service Handbook 5109.11. Washington, DC: U.S. Department of Agriculture, Forest Service; 1964.

Van Wagner, C. E. Duff consumption by fire in eastern pine stands. Canadian Journal of Forest Research. 2: $34-39 ; 1972$.

Van Wagner, C. E. Structure of the Canadian Forest Fire Weather Index. Publication No. 1333. Ottawa, Canada: Department of the Environment, Canadian Forestry Service; 1974. 44 p. 


\section{APPENDIX I. ADJUSTING FUEL DIAMETER CLASSES}

In all studies, loadings of downed woody material were determined using the planar intersect method where counts of particles by diameter class are converted to loadings (Brown 1974). To convert particle count data from 0 - to 0.4 -inch $(0-$ to $1-\mathrm{cm})$ and 0.4 - to 4 -inch (1- to $10-\mathrm{cm}$ ) classes used in the Miller-Newman study to the conventional classes, it was assumed that the frequency of fuel pieces by diameter could be represented by a single probability distribution (fig.17). The relative frequency of intercepts in the diameter classes in (A) was partitioned into the diameter classes in (B) (fig. 17) using data on diameters from randomly intersected particles.

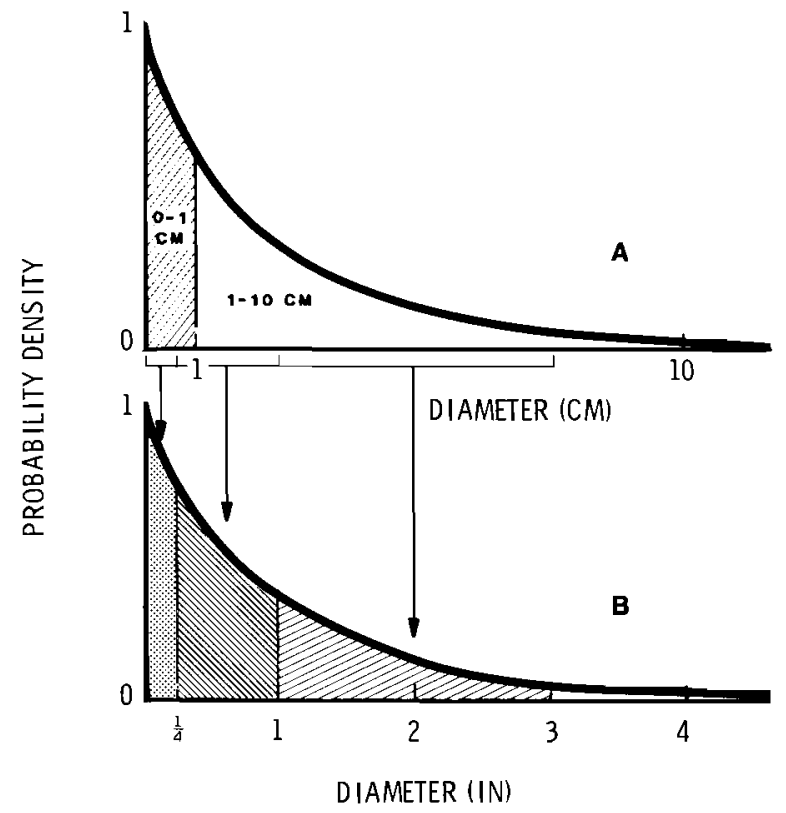

Allocating intercepts to the 0 - to $1 / 4$-inch class.- Using data from a study by Brown and Roussopoulos (1974), it was determined that 95 percent of the intercepts in the 0 - to 0.4 -inch class were less than one-fourth inch. The adjusted frequency for the 0 - to $1 / 4$-inch class is then 0.95 times the frequency of intercepts in the 0 - to 0.4 -inch class. It follows that the remaining intercepts in the 0to 0.4 -inch class would be part of the $1 / 4$ - to 1 -inch class.

Allocating intercepts to the $1 / 4$ - to 1 -inch class. - This class includes intercepts from the upper end of the 0 - to 0.4 -inch class and a portion of the 0.4 - to 4 -inch class. The proportion of fuel pieces between 0.4 and 1 inch was calculated by species using intercept data from the Miller Creek and Newman Ridge Study (table 8). The allocation of intercepts at a given sample point can be expressed by:

$$
Y_{1}=0.05 X_{1}+X_{2}\left(\stackrel{j}{=}=1_{j}^{8} P_{j} R_{j, 1}\right)
$$

where

$\mathrm{Y}_{1}=$ frequency of intercepts allocated to the $1 / 4-$ to 1 -inch class

$\mathrm{X}_{1}=$ sample frequency for the 0 - to 0.4 -inch class

$\mathrm{X}_{2}=$ sample frequency for the 0.4 - to 4 -inch class

$P_{j}=$ fraction of slash estimated to be the $j^{\text {th }}$ species

$R_{j, 1}=$ fraction of $j$ th species 0.4 - to 4 -inch class that is 0.4 to 1 inch.

Allocating intercepts to the 1- to 3 -inch class.-This class is the mid-portion of the 0.4 - to 4 -inch class. It can be expressed as:

$$
\mathrm{Y}_{2}=\mathrm{X}_{2}\left(\sum_{\mathrm{j}=1}^{8} \mathrm{P}_{\mathrm{j}} \mathbf{R}_{\mathrm{i}, 2}\right)
$$

where

$$
\mathrm{Y}_{2}=\text { frequency of intercepts allocated to the 1- to }
$$
3-inch class

$R_{i .2}=$ fraction of the $j^{\text {th }}$ species 0.4 - to 4 -inch class that is 1 to 3 inches.

Figure 17. - Fuel particle diameter distribu. tions showing the size classes used at Miller-Newman (A) and the conventional diameter classes used in the other studies (B).

Table 8.-Fractions of particle intercepts by species and diameter classes at Miller Creek and Newman Ridge

\begin{tabular}{lccc}
\hline & \multicolumn{3}{c}{ Diameter classes } \\
\cline { 2 - 4 } \multicolumn{1}{c}{ Species } & $\begin{array}{c}\mathbf{0 . 4} \text { to } \mathbf{1} \text { inch } \\
(\mathbf{1} \text { to } \mathbf{2 . 5} \mathbf{~ c m})\end{array}$ & $\begin{array}{c}\mathbf{1} \text { to } \mathbf{3} \text { inches } \\
(\mathbf{2 . 5} \text { to } 7.6 \mathrm{~cm})\end{array}$ & $\begin{array}{c}\mathbf{3} \text { to } \mathbf{4} \text { inches } \\
(\mathbf{7 . 6} \text { to } \mathbf{1 0} \mathbf{~ c m})\end{array}$ \\
\hline Western larch & 0.43 & 0.55 & 0.02 \\
Douglas-fir & .44 & .51 & .05 \\
Subalpine fir & .53 & .44 & .03 \\
Grand fir & .53 & .44 & .03 \\
Lodgepole pine & .44 & .50 & .06 \\
Engelmann & & & .01 \\
$\quad$ spruce & .71 & .36 & .01 \\
Ponderosa pine & .63 & .36 & .01 \\
Western redcedar & .63 & & \\
\end{tabular}


APPENDIX II. CORRELATIONS AMONG VARIABLES

Table 9.- Simple correlation coefficients ${ }^{1}$ between transformed and untransformed duff consumption variables

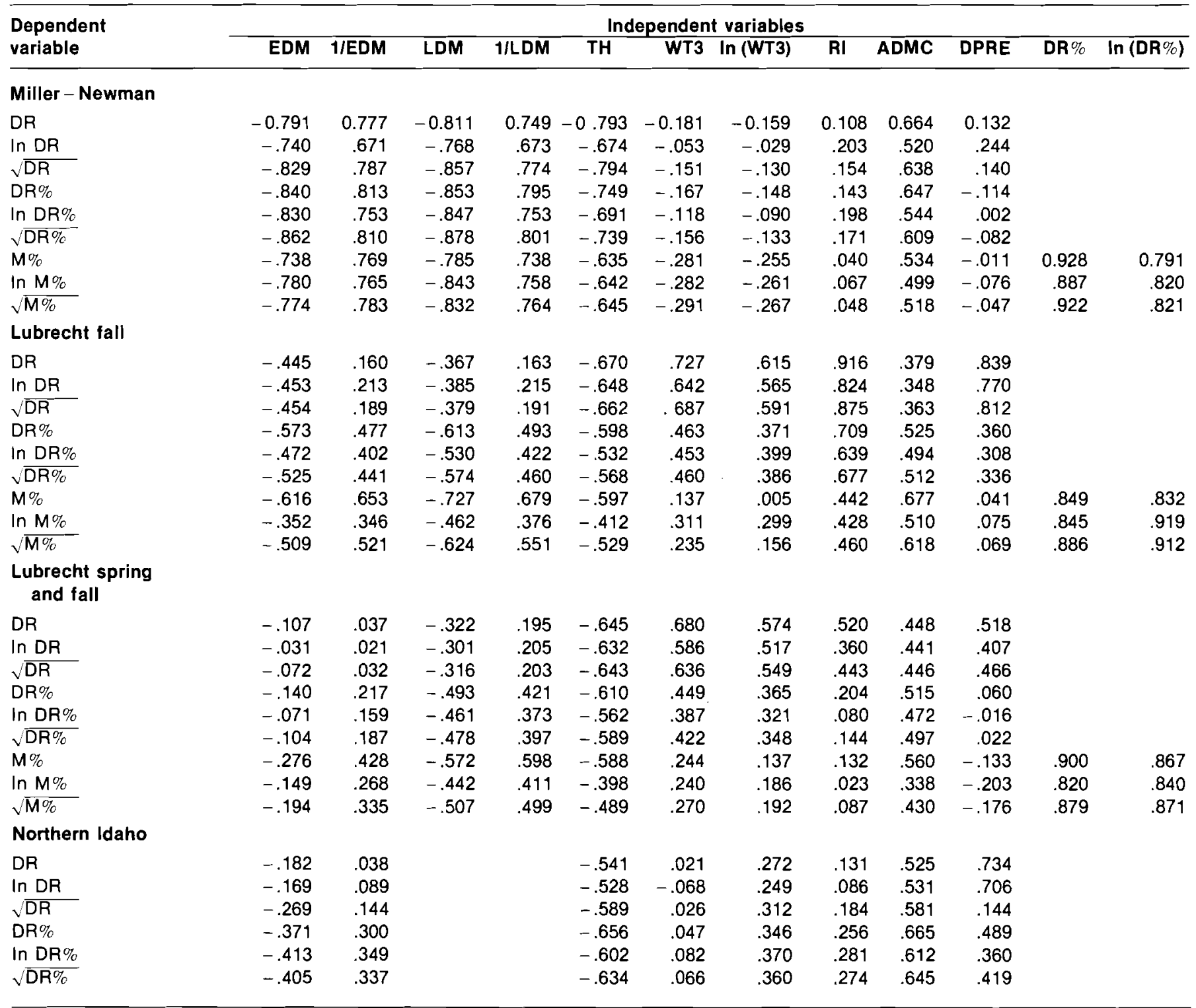

${ }^{1}$ Significance levels for $r$ at 90 and 95 percent levels listed respectively are 0.211 and $0.250, M N ; 0.521$ and $0.602, L_{f} ; 0.389$ and $0.456, L_{S} ;$ and 0.243 and 0.288 , NI. 


\section{APPENDIX III. EQUATIONS IN METRIC UNITS}

Table 10.- Metric units for equations and related statistics on precision and bias

\begin{tabular}{|c|c|c|c|c|c|c|c|}
\hline & & & \multicolumn{5}{|c|}{ Centimeters } \\
\hline 2 & $\mathrm{MN}$ & $\mathrm{DR}=4.574-0.0201 \mathrm{LDM}$ & .87 & .86 & 1.78 & 1.26 & - \\
\hline 3 & $M N, L_{\dagger}$ & $\mathrm{DR}=2.238-0.0244 \mathrm{EDM}+0.439 \mathrm{DPRE}$ & .85 & .80 & 1.00 & 2.19 & 2.33 \\
\hline 4 & $\mathrm{MN}$ & $\mathrm{DR}=4.272-0.0215 \mathrm{EDM}$ & .91 & .90 & 1.92 & 1.38 & 2.90 \\
\hline 7 & $M N, L_{f}$ & $\mathrm{DR}=1.04+0.0179 \mathrm{ADMC}$ & 1.16 & 1.01 & 1.71 & .69 & 1.64 \\
\hline 8 & $M N, L_{f}$ & $\mathrm{DR} \%=87.8-0.390$ LDM & 14.1 & 14.4 & 11.5 & 28.5 & - \\
\hline \multirow[t]{2}{*}{9} & $M N, L_{f}$ & DR\% $=97.1-0.519$ LDM, LDM $\leq 160 \%$ & & & & & \\
\hline & & $=13.6, \mathrm{LDM}>160 \%$ & 13.5 & 13.6 & 11.6 & 27.8 & - \\
\hline 10 & $M N, L_{f}$ & $\mathrm{DR} \%=83.7-0.426 \mathrm{EDM}$ & 14.7 & 14.9 & 11.7 & 33.1 & 51.3 \\
\hline 15 & $M N, L_{f}$ & $\mathrm{DR} \%=21.2+0.293 \mathrm{ADMC}$ & 18.9 & 19.6 & 12.2 & 17.2 & 23.4 \\
\hline 16 & $M N, L_{f}$ & $\mathrm{DR} \%=15.2+0.948 \mathrm{M} \%$ & 9.9 & 8.0 & 15.7 & 5.4 & - \\
\hline \multirow[t]{2}{*}{17} & $M N, L_{f}$ & $\mathrm{M} \%=80.0-0.507$ LDM, LDM $\leq 135 \%$ & & & & & \\
\hline & & $=23.5-0.0914$ LDM, LDM $>135 \%$ & 16.1 & 15.7 & 17.0 & 28.3 & - \\
\hline 18 & $\mathrm{~L}_{\mathrm{f}}$ & $\mathrm{M} \%=60.4-0.440 \mathrm{LDM}$ & 10.0 & 27.3 & 9.1 & 17.4 & - \\
\hline 19 & $M N, L_{f}$ & $\mathrm{M} \%=167.4-31.6 \ln (\mathrm{EDM})$ & 16.4 & 16.5 & 14.6 & 33.5 & - \\
\hline 20 & $M N, L_{f}, L_{s}$ & $\mathrm{M} \%=51.7-0.357$ LDM +0.4386 WT3 & 16.7 & 17.3 & 9.2 & 16.8 & - \\
\hline 21 & MN & $\mathrm{M} \%=93.0-3.55 \mathrm{TH}$ & 20.3 & 20.0 & 21.3 & 32.2 & - \\
\hline 22 & $\mathrm{~L}_{\mathrm{f}}$ & $M \%=94.3-4.96 \mathrm{TH}$ & 11.7 & 30.9 & 10.6 & 14.4 & - \\
\hline 23 & $M N, L_{f}$ & $\mathrm{M} \%=-8.98+0.899 \mathrm{DR} \%$ & 9.6 & 7.9 & 15.2 & 7.5 & - \\
\hline 24 & MN & CWT1 $=0.437+0.831 \mathrm{WT1}$ & 1.039 & 1.019 & 1.366 & 1.456 & 1.210 \\
\hline 25 & MN & CWT3 $=-2.779+0.873$ WT3 & 4.500 & 4.429 & 1.612 & 2.265 & 2.220 \\
\hline
\end{tabular}

1DR, DPRE: $\mathrm{cm}$

WT1, WT3, WTLG. CWT1, CWT3, CWTLG: t/ha. 


\section{APPENDIX IV. COMPARING FIRE WEATHER INDICES}

Table 11.-Statistics for comparing regression relationships between fire weather indices and duff consumption

\begin{tabular}{|c|c|c|c|c|c|c|c|c|}
\hline \multirow{2}{*}{$\begin{array}{l}\text { Data } \\
\text { set }\end{array}$} & \multicolumn{2}{|c|}{ DC } & \multicolumn{2}{|c|}{ DMC } & \multicolumn{2}{|c|}{ ADMC } & \multicolumn{2}{|c|}{ TH } \\
\hline & $r^{2}$ & $\overline{\text { se }}$ & $r^{2}$ & $\overline{\text { se }}$ & $r^{2}$ & $\overline{\text { se }}$ & $r^{2}$ & $\overline{\text { se }}$ \\
\hline \multicolumn{9}{|c|}{ Duff Depth Reduction } \\
\hline & & Inch & & Inch & & Inch & & Inch \\
\hline$L_{\varphi}$ & 0.05 & 0.71 & 0.14 & 0.67 & 0.12 & 0.68 & 0.45 & 0.54 \\
\hline$M N$ & .30 & .49 & .44 & .44 & .54 & .40 & .63 & .36 \\
\hline$M N, L_{f}$ & .28 & .55 & .34 & .51 & .48 & .47 & .58 & .43 \\
\hline $\mathrm{NI}$ & .28 & .26 & .28 & .26 & .28 & .26 & .29 & .26 \\
\hline$L_{f}, \mathrm{NI}$ & .61 & .39 & .33 & .51 & .40 & .47 & .68 & .35 \\
\hline All & .08 & .57 & .33 & .49 & .37 & .48 & .55 & .42 \\
\hline \multicolumn{9}{|c|}{ Duff Depth Reduction } \\
\hline & & Pct & & Pct & & Pct & & Pct \\
\hline$L_{f}$ & 0.00 & 15.3 & 0.28 & 13.0 & 0.26 & 12.7 & 0.36 & 12.3 \\
\hline$M N$ & .23 & 23.1 & .28 & 22.3 & .49 & 19.9 & .56 & 18.5 \\
\hline$M N, L_{f}$ & .15 & 24.4 & .44 & 19.9 & .53 & 18.2 & .61 & 16.6 \\
\hline $\mathrm{NI}$ & .44 & 11.3 & .44 & 11.3 & .45 & 11.2 & .43 & 11.4 \\
\hline$L_{f}, N I$ & .54 & 12.6 & .51 & 13.0 & .56 & 12.6 & .64 & 11.5 \\
\hline All & .03 & 24.2 & .43 & 18.9 & .42 & 18.7 & .59 & 16.1 \\
\hline \multicolumn{9}{|c|}{ Mineral Soil Exposure } \\
\hline$L_{f}$ & 0.01 & 14.6 & 0.46 & 10.8 & 0.44 & 11.0 & 0.36 & 11.7 \\
\hline $\mathrm{MN}$ & .23 & 23.1 & .28 & 22.2 & .35 & 21.1 & .40 & 20.4 \\
\hline$M N, L_{f}$ & .03 & 24.5 & .29 & 21.0 & .33 & 20.3 & .37 & 19.8 \\
\hline \multicolumn{9}{|c|}{ Lower Duff Moisture Content } \\
\hline$M N, L$ & - & - & 0.30 & 45.5 & 0.39 & 42.3 & 0.53 & 37.1 \\
\hline
\end{tabular}


Brown, James K.; Marsden, Michael A.; Ryan, Kevin C.; Reinhardt, Elizabeth D. Predicting duff and woody fuel consumed by prescribed fire in the Northern Rocky Mountains. Research Paper INT-337. Ogden, UT: U.S. Department of Agriculture, Forest Service, Intermountain Forest and Range Experiment Station; $1985.23 \mathrm{p}$.

Relationships for predicting duff reduction, mineral soil exposure, and consumption of downed woody fuel were determined to assist in planning prescribed fires. Independent variables included lower and entire duff moisture contents, loadings of downed woody fuels, duff depth, National Fire-Danger Rating System 1,000-hour moisture content, and Canadian Duff Moisture Codes. Results apply to a number of mesic forest cover types.

KEYWORDS: fuel consumption, duff, downed woody fuel, forest fuels, prescribed fire 